\title{
Controlling the HIV/AIDS epidemic: current status and global challenges
}

\section{Thorsten Demberg * and Marjorie Robert-Guroff}

Vaccine Branch, Section on Immune Biology of Retroviral Infection, National Cancer Institute, National Institutes of Health, Bethesda, MD, USA

\section{Edited by:}

Marc H. V. Van Regenmortel,

University of Strasbourg, France

Reviewed by:

Marc H. V. Van Regenmortel,

University of Strasbourg, France

Marc P. Girard, University

Paris-Diderot, France

Catarina E. Hioe, New York

University School of Medicine, USA

\section{*Correspondence:}

Thorsten Demberg, Vaccine Branch, National Cancer Institute, National Institutes of Health, 41 Medlars

Drive, Building 41, Room D804,

Bethesda, MD 20892-5065, USA.

e-mail:dembergt@mail.nih.gov
This review provides an overview of the current status of the global HIV pandemic and strategies to bring it under control. It updates numerous preventive approaches including behavioral interventions, male circumcision (MC), pre- and post-exposure prophylaxis (PREP and PEP), vaccines, and microbicides. The manuscript summarizes current anti-retroviral treatment options, their impact in the western world, and difficulties faced by emerging and resource-limited nations in providing and maintaining appropriate treatment regimens. Current clinical and pre-clinical approaches toward a cure for HIV are described, including new drug compounds that target viral reservoirs and gene therapy approaches aimed at altering susceptibility to HIV infection. Recent progress in vaccine development is summarized, including novel approaches and new discoveries.

Keywords: animal model, ART treatment, global strategies, HIV pandemic, prevention, vaccine development

\section{INTRODUCTION}

Beginning with the FDA approval of AZT in 1987 for HIV treatment and the subsequent development of combination therapies, millions of HIV infected people have been saved from progression to AIDS, and their quality of life has improved dramatically (Broder, 2010). An outgrowth of the successful advances in AIDS treatment regimens is the recent finding that early initiation of antiretroviral therapy (ART) can reduce HIV transmission by 96\% (Cohen et al., 2011). Moreover, mother-to-child transmission can be prevented using anti-HIV drugs, as recently reviewed for low- and middle-income countries (Siegfried et al., 2011; Tudor Car et al., 2011; Santos et al., 2012). The challenges of implementing such "treatment as prevention" strategies are many, however, as reviewed here. Overall, in addition to pursuing new developments in treatment, all available preventive measures as well as continued research efforts toward an efficacious HIV vaccine should be employed to effectively control the HIV/AIDS pandemic.

\section{FACTS AND FINANCES: THE GLOBAL CHALLENGE OF HIV INFECTION}

Human immunodeficiency virus (HIV) infection and the incurable disease, acquired immunodeficiency syndrome (AIDS), present major global health problems. Approximately 34 million people worldwide are currently living with HIV, 1-1.2 million of these in the United States (Table 1). The overall US HIV infection rate has remained steady since the 1990s with around 49,000 cases per year, the majority in men having sex with men (MSM) (Moore, 2011; Morris and Little, 2011; Prejean et al., 2011). Moreover, the global HIV prevalence is expected to increase within the next 10 years (Yehia and Frank, 2011), indicating that action on a national and international level is needed. The current standard of care is ART which requires daily medication to prevent disease progression and re-emergence of the virus. However, co-infection of HIV infected patients with tuberculosis or hepatitis as well as sexually transmitted diseases, together with problems in health care systems and infrastructure, have an impact on treatment success (Beauliere et al., 2010; Obiako and Muktar, 2010; Birbeck et al., 2011; Boesecke and Vogel, 2011; Finlayson et al., 2011).

ART is expensive as illustrated by costs in the US that average $\$ 30,000 /$ year/patient and are similarly high in European countries (Table 1) (Fleishman et al., 2010; Gebo et al., 2010; Colombo et al., 2011; Hill et al., 2011; Krentz and Gill, 2012). Despite multi-tier pricing models (Wirtz et al., 2009), global costs for treatment are high (Table 1) and current predictions call for over 1.7 billion dollars per year to fight HIV in lowand middle-income countries (Nunn et al., 2007; Stover et al., 2011). Moreover, the future of outside funding for treatment (e.g., PEPFAR, the President's Emergency Plan for AIDS Relief) under current global economic conditions is tenuous, as a drop in funding due to the weakened global economy has been reported with consequences for programs and patients in Africa (Voelker, 2011; Wasswa, 2011). Worldwide, treatment costs impact families, economies and health care systems. In the US alone, therapy for STDs and HIV cost from 14 to 23 billion dollars a year (Chesson et al., 2011). HIV/AIDS is associated with poverty, lower education and minority populations (Torrone et al., 2010; Vermund et al., 2010; Dang et al., 2011; Espinoza et al., 2012). Only $15-17 \%$ people living with HIV have private insurance and nearly $30 \%$ in the US do not have any coverage (Espinoza et al., 2012; http://healthcare.gov/news/factsheets/affordable_care_act_ people_hiv_aids.html). Since up to $21 \%$ of these groups would likely be starting treatment in an advanced disease state due to unawareness, late detection of infection (Moore, 2011; Yehia and Frank, 2011; Espinoza et al., 2012) or being undocumented 
Table 1 | HIV/AIDS: facts and finance.

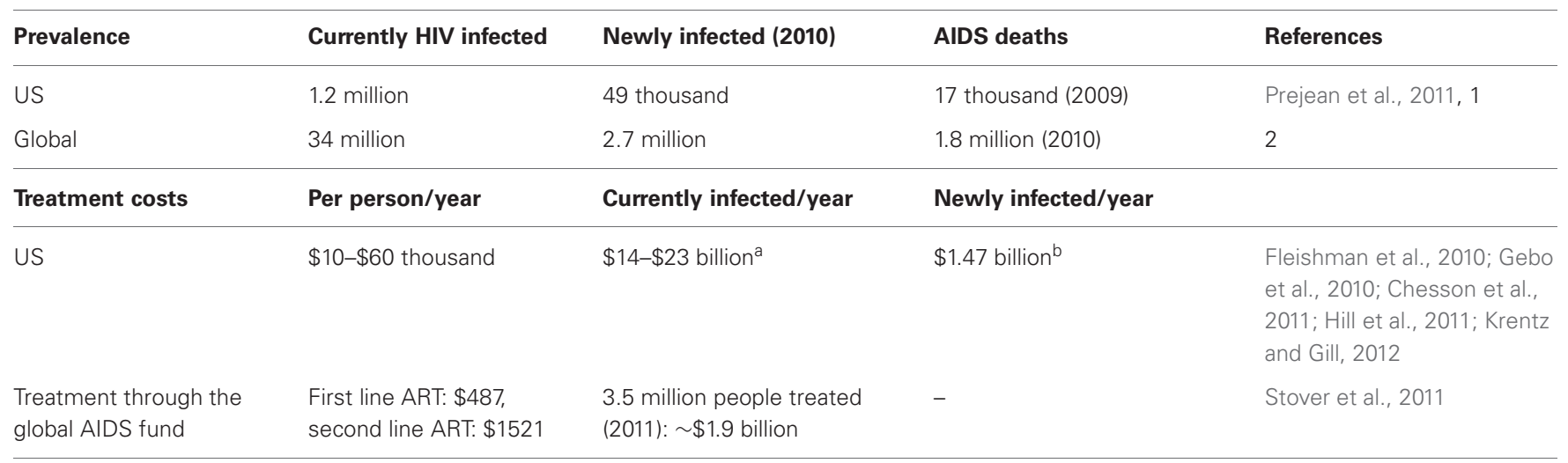

a Estimated cost for treatment of STDs and HIV.

${ }^{b}$ Estimated using $\$ 30,000$ per person, per year.

1. http://www.cdc.gov/hiv/resources.factsheets/us.htm

2. http://www.who.int/hiv/data/2011_epi_core_en.png

(Dang et al., 2011), costs for therapy would be higher. Measures to prevent HIV infection at the outset would provide a significant financial benefit by lowering health care costs. Overall, finding measures to prevent HIV infection or affect a cure are of highest importance for the broadest benefit to public health (Long and Owens, 2011).

\section{WORLDWIDE IMPLEMENTATION OF ART}

Effective treatment enables HIV infected individuals to be productive members of society, a critical economic benefit (Resch et al., 2011). However, making treatment worldwide readily available is a challenge. Aside from high costs (Table 1), successful initiation and maintenance of AIDS therapy in emerging countries and the developing world can be limited by political and sociological factors including instability of governments and health care systems, transportation problems and poor nutrition (Beauliere et al., 2010; Obiako and Muktar, 2010; Birbeck et al., 2011). If disease is diagnosed late as often occurs in developing countries, treatment success can be diminished due to late stage AIDS, HIV-associated dementia and opportunistic infection requiring additional, often unavailable, treatment. Social barriers such as personal and family shame or blame and societal stigma, often paired with insufficient education on HIV/AIDS, can also prevent individuals from seeking treatment (Amuri et al., 2011; Dang et al., 2011; Winskell et al., 2011; Espinoza et al., 2012; Steward et al., 2012).

The overall benefits outweigh by far the side effects of ART medications. However, in the course of treatment new problems surface and medical care has to be adjusted accordingly (Llibre et al., 2009) which can be difficult in the developing world. ART can induce immune reconstitution inflammatory syndrome upon initiation, making the monitoring of CD4 Tcells, viral load, liver, and kidney function crucial for successful treatment (Kalyesubula and Perazella, 2011; Keiser et al., 2011; Barber et al., 2012). Further, there is a tendency for HIV infected patients on ART to show increased kidney damage in addition to HIV associated nephropathy and cardiovascular disease.
An increased risk for myocardial infarct has been attributed to the protease inhibitors lopinavir/ritonavir and the transcriptase inhibitor abacavir (Fichtenbaum, 2010; Islam et al., 2012a,b; Maggi et al., 2012). Markers of systemic inflammation (c-reactive protein, IL-6), coagulation, and renal function are elevated in HIV infected patients independent of successful suppression of viremia (Neuhaus et al., 2011; Bastard et al., 2012). The elevated inflammatory markers can indicate ongoing low level viral replication in tissues only minimally reached by ART and subsequent cell-to-cell viral spread, as ART does not completely reverse T-cell activation (D'Ettorre et al., 2011). In addition to T-cell activation, B-cell abnormalities and loss of memory B-cells persist despite long-term treatment with ART (Chong et al., 2004; Moir and Fauci, 2009). B-cell lymphomas and other cancers (e.g., squamous cell carcinoma) are increasing in HIV infected patients (Carbone et al., 2009; Epeldegui et al., 2010; Gervaz et al., 2011; Tyerman and Aboulafia, 2012) requiring additional treatment.

First line combination therapy, consisting of one nonnucleoside reverse transcriptase inhibitor (NNRTI) and two nucleoside reverse transcriptase inhibitors (NRTI) as recommended by the $\mathrm{WHO}$, is often the only available form of treatment in low-income countries (www.who.int/hiv/pub/arv/adult2010/ en/index.html). As of December, 2010, in 45 low- and middleincome countries excluding the Americas, of the $81 \%$ of patients receiving treatment, $97 \%$ were on first-line regimens ( $>54 \%$ on Nevirapine, Lamivudine and Stavudine, or Zidovudine) and only $2.9 \%$ on significantly more costly second line treatment regimens (www.who.int/hiv/pub/progress_report2011/en/). As a result, this can lead to the emergence of viral resistance to first line treatment. To combat this problem, frequent monitoring of viral loads and strict treatment adherence to the drug regimen are important, but can be problematic (Birbeck et al., 2011). Over time despite treatment adherence and maintenance of viral load suppression, resistance develops in about 30\% of patients. Not only does this result in treatment failure, the resistant viruses can be transmitted, cause new infections that are not controlled by the existing drug regimen (Hamilton et al., 2012; von Wyl et al., 
2011), and jeopardize future treatment options (Chamberland et al., 2011). Especially, concerning is the frequency of viral resistance to first-line ART that arises among children in resource poor countries (Sigaloff et al., 2011). Resistance mutations vary depending on the type of drug regimen. However, regardless of the mechanism, resistance to ART develops inexorably, showing the urgent need not only for new treatments but also alternative preventive measures.

\section{ADDITIONAL APPROACHES TO PREVENT INFECTION}

In spite of the dramatic reports of preventing HIV transmission using early ART, other studies have suggested that testing and early treatment alone might not significantly reduce HIV transmission in the near future, as predicted by a study in Washington, DC (Walensky et al., 2010), a current "hot-spot" of HIV infection (Greenberg et al., 2009; Carr et al., 2010; Hanna et al., 2011). To be prudent, additional measures, of which there are several, would enhance the likelihood of successful prevention. Among the easiest is syringe and needle exchange programs. HIV is most commonly transmitted by sexual contact. However, transmission also occurs among intravenous drug users (IDU) via needle and syringe sharing (Nacopoulos et al., 2010; Vlahov et al., 2010). In the US approximately $12 \%$ of all new HIV infections per year occur in IDU (Adimora and Auerbach, 2010). Syringe and needle exchange programs provide a simple, inexpensive preventive measure in this population (Adimora and Auerbach, 2010; Nacopoulos et al., 2010; Vlahov et al., 2010).

Sexual transmission of HIV is best prevented by practicing safe sex or abstinence, both confounded by multifaceted behaviors. Failure to practice safe sex may be due to lack of knowledge about HIV infection and treatment, and perhaps the assumption that ART cures HIV (Owoaje et al., 2011; Smith et al., 2011). Other factors include gender inequity of woman, particularly in negotiating condom use, and partner violence (Jewkes et al., 2010; East et al., 2011; El-Bassel et al., 2011; Fair and Vanyur, 2011; Gakumo et al., 2011; Swan and O'Connell, 2011). Additionally, alcohol and substance abuse influence personality traits and risk behavior, and lower the frequency and ability to negotiate condom use (Tapert et al., 2001; Kogan et al., 2010; Finlayson et al., 2011; Hagger-Johnson et al., 2011; Maisto et al., 2012; Rehm et al., 2012). Selected clinical trials that address behavioral modification are listed in Table 2. Behavioral modification is difficult, however, and mixed results have been obtained. Of five investigated interventions (billboards, peer education, magazines, radio broadcasts, and public outreach events) the latter three were significantly correlated with increased condom use, but the overall influence on behavior was limited (Hsu et al., 2012). In another study, behavioral interventions among 725 HIV-positive women had no effect on increased condom use (Carvalho et al., 2011). Behavioral interventions in the workplace, including voluntary counseling and testing to reduce risky sexual behavior, found no reduction in HIV incidence rate or frequency of unprotected sex, although, education did reduce unprotected sex, STDs and sex with commercial sex workers (Ojo et al., 2011).

To augment safe sex practices and abstinence, oral/systemic pre-exposure prophylaxis (PREP) has been shown effective in preventing HIV infection both in non-human primates and humans (Tsai et al., 1994a,b; Grant et al., 2010; Myers and Mayer,

Table 2 | Selected clinical trials targeting behavior modification as a measure to prevent HIV infection.

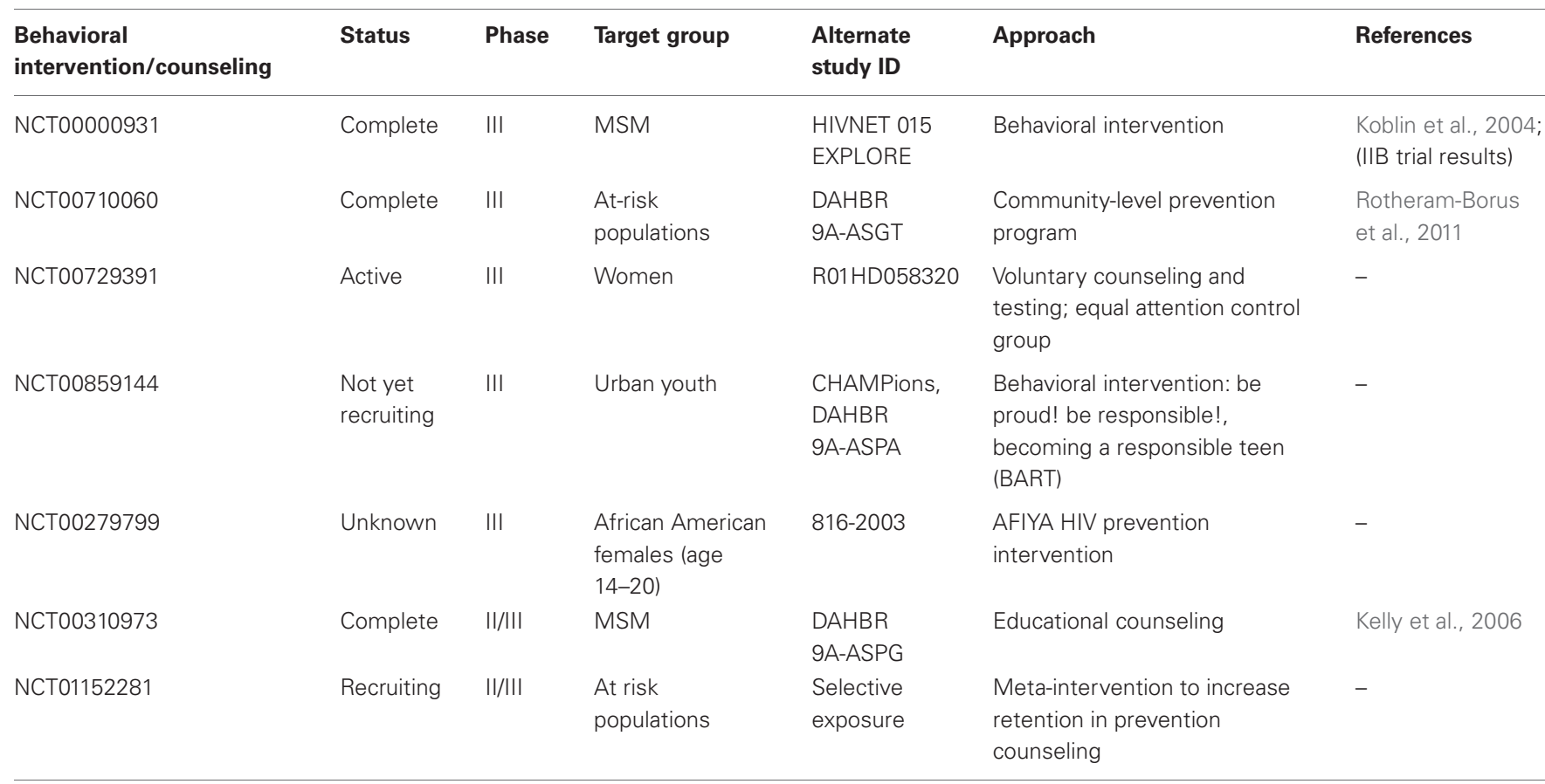

More information about the individual trials can be found using the NCT number and the following databases: www.aidsinfo.nih.gov/clinical-trials; www.clinicaltrials.gov; http://www.avac.org. 
2011). It must be used consciously and before sexual activity in order to achieve a sufficient inhibitor concentration. Reduction in HIV acquisition is dependent on adherence to PREP use and ranges from 21 to 73\% (Krakower and Mayer, 2011; Naswa and Marfatia, 2011). Factors associated with PREP failure are similar to those of condom use, including failure to have the medication on hand and adherence (Golub et al., 2010; van der Straten et al., 2012). Questions concerning the implementation of PREP and guidelines for its use are both scientific (e.g., oral vs. mucosal) and policy related (e.g., insurance coverage of treatment expenses) (Myers and Mayer, 2011; Naswa and Marfatia, 2011). Current cost estimates for PREP for 100,000 high risk persons in the US are over $\$ 1$ billion a year (\$900 in medication costs per month) (Leibowitz et al., 2011), making the implementation of PREP in tough economic times unlikely despite potential long-term benefits (Koppenhaver et al., 2011). Further, emergence of drug resistance is a potential pitfall for PREP users but might have only a negligible impact as shown for MSM in the UK (Dolling et al., 2011).

Post-exposure prophylaxis (PEP) or post-exposure prophylaxis following sexual exposure (PEPSE) must be used conscientiously and requires a long follow up interval of up to 6 months post-exposure as recommended by the CDC (www.cdc. gov/mmwr/preview/mmwrhtml/rr5402al.htm) (McCarty et al., 2011). PEPSE awareness in high risk groups has increased significantly, but its use in general is low (Zablotska et al., 2011). However, PEP after accidental exposure (e.g., needle stick injury) or for victims of sexual assault and rape has a proven track record of preventing infection. As for PREP, timing is critical. Treatment should not be delayed more than $72 \mathrm{~h}$ post exposure without a significant chance of infection. Table 3 lists selected clinical trials for PREP and PEP. For further information on PREP and PEP methods, strategies, costs, etc. see Fernandez-Montero et al. (2012).

Microbicide development for HIV prophylaxis is another active area of research. A number of microbicide candidates have been tested in clinical trials (Table 4), but few have shown efficacy, and some have possibly enhanced HIV acquisition (Tao et al., 2008; Abdool Karim et al., 2010, 2011; Pirrone et al., 2011, 2012). The gel base for microbicides must be chosen cautiously, as some can cause epithelial damage facilitating HIV infection (Begay et al., 2011). The latest microbicides containing

Table 3 | Selected clinical trials investigating PrEP and PEP for prevention of HIV infection.

\begin{tabular}{|c|c|c|c|c|c|c|}
\hline $\begin{array}{l}\text { Trial } \\
\text { identifier }\end{array}$ & Status & Phase & Target group & $\begin{array}{l}\text { Alternate } \\
\text { study ID }\end{array}$ & Component & $\begin{array}{l}\text { Comment/ } \\
\text { references }\end{array}$ \\
\hline \multicolumn{7}{|l|}{ PrEP } \\
\hline NCT00931346 & Complete & $1 / I I$ & $\begin{array}{l}\text { HIV discordant } \\
\text { couples }\end{array}$ & IAVI E002 & $\begin{array}{l}\text { Emtricitabine/tenofovir } \\
\text { disoproxil fumarate }\end{array}$ & - \\
\hline NCT01473472 & $\begin{array}{l}\text { Not yet } \\
\text { recruiting }\end{array}$ & III & MSM & IPERGAY & $\begin{array}{l}\text { Emtricitabine and } \\
\text { tenofovir disoproxil } \\
\text { fumarate (truvada) }\end{array}$ & - \\
\hline NCT01275443 & Recruiting & I & $\begin{array}{l}\text { People at risk for } \\
\text { HIV }\end{array}$ & SSAT 040 & $\begin{array}{l}\text { TMC278 (rilpivirine), } \\
\text { long-acting } \\
\text { formulation }\end{array}$ & - \\
\hline NCT00594646 & Complete & IV & $\begin{array}{l}\text { High-risk sexual } \\
\text { contact }\end{array}$ & MK PEP 2007 & $\begin{array}{l}\text { Fixed-dose tenofovir } \\
\text { and raltegravir }\end{array}$ & - \\
\hline NCT00385645 & Complete & IV & $\begin{array}{l}\text { Accidental HIV } \\
\text { exposure }\end{array}$ & DATEM-PEP & $\begin{array}{l}\text { AZT-3TC + } \\
\text { lopinavir-ritonavir vs. } \\
\text { ZT-3TC + atazanavir }\end{array}$ & - \\
\hline NCT01140880 & Recruiting & II & MSM & $\begin{array}{l}\text { MC08-LA-710- } \\
\text { FRI }\end{array}$ & $\begin{array}{l}\text { Emtricitabine and } \\
\text { tenofovir disoproxil } \\
\text { fumarate (truvada) }\end{array}$ & - \\
\hline NCT00949234 & Recruiting & II & $\begin{array}{l}\text { High-risk sexual } \\
\text { contact }\end{array}$ & PQUAD & $\begin{array}{l}\text { Tenofovir + } \\
\text { emtricitabine, } \\
\text { lopinavir/ritonavir }\end{array}$ & - \\
\hline
\end{tabular}

More information about the individual trials can be found using the NCT number and the following databases: www.aidsinfo.nih.gov/clinical-trials; www.clinicaltrials.gov; http://www.avac.org. 
Table 4 | Selected clinical trials of microbicides.

\begin{tabular}{|c|c|c|c|c|c|c|}
\hline Microbicides & Status & Phase & $\begin{array}{l}\text { Type of } \\
\text { prevention }\end{array}$ & $\begin{array}{l}\text { Alternate } \\
\text { study ID }\end{array}$ & Component & $\begin{array}{l}\text { Comment/ } \\
\text { references }\end{array}$ \\
\hline NCT00262106 & Complete & III & Gel, vaginal & $\begin{array}{l}\text { MDP301, } \\
\text { ISRCTN64716212 }\end{array}$ & $\begin{array}{l}\text { PRO } 2000 / 5 \mathrm{gel} \\
0.5 \% \text { and } 2 \%\end{array}$ & $\begin{array}{l}\text { Not efficacious; } \\
\text { McCormack } \\
\text { et al., } 2010\end{array}$ \\
\hline NCT00153777 & Terminated & III & Gel, vaginal & $\begin{array}{l}\text { CONRAD, } \\
\text { C03-090 }\end{array}$ & $\begin{array}{l}\text { Cellulose sulfate } \\
\text { gel }(6 \%)\end{array}$ & $\begin{array}{l}\text { No protection, } \\
\text { possible } \\
\text { enhancement; } \\
\text { Van Damme } \\
\text { et al., } 2008\end{array}$ \\
\hline NCT00213083 & Unknown & III & Gel, vaginal & $\begin{array}{l}\text { Population } \\
\text { council \#322 }\end{array}$ & $\begin{array}{l}\text { Carraguard } \\
\text { (PC-515) }\end{array}$ & $\begin{array}{l}\text { No protection; } \\
\text { Skoler-Karpoff } \\
\text { et al., } 2008\end{array}$ \\
\hline NCT00740584 & Complete & $|/| 1$ & Gel, vaginal & $\begin{array}{l}\text { SPL7013-003, } \\
\text { DAIDS ES } \\
\text { number } \\
10730\end{array}$ & $\begin{array}{l}\text { 3\% SPL7013 gel } \\
\text { (VivaGel) }\end{array}$ & Price et al., 2011 \\
\hline NCT00850837 & Recruiting & I & Gel, vaginal & AF 020 & $\begin{array}{l}\text { Acidform } \\
\text { lubricant } \\
\text { (Amphora) }\end{array}$ & - \\
\hline
\end{tabular}

More information about the individual trials can be found using the NCT number and the following databases: www.aidsinfo.nih.gov/clinical-trials; www.clinicaltrials.gov; http://www.avac.org.

1. http://www.niaid.nih.gov/news/newsreleases/2011/Pages/VOICEdiscontinued.aspx

Tenofovir, a reverse transcriptase inhibitor, have shown promising but modest efficacy, as in the CAPRISA trial (Abdool Karim et al., 2010). However, a recent clinical trial (VOICE, MTN-003) evaluating daily use of a vaginal gel containing Tenofovir in over 5000 woman was discontinued, as interim analysis showed no difference in HIV incidence rate compared to use of a placebo gel (Table 4). Among new approaches, evaluation of topical 2-Hydroxypropyl-beta-cyclodextrin has shown promise in an animal model (Ambrose et al., 2008), as have live lactobacilli engineered to secrete cyanovirin (Lagenaur et al., 2011). The latter approach if successful might alleviate problems of adherence by reducing the need for application just prior sexual exposure. In the Carraguard trial self-reported microbicide use was $96 \%$, but applicator testing revealed actual adherence was only $42 \%$ (Skoler-Karpoff et al., 2008). Microbicides under development are incorporating other ART components such as integrase, protease or reverse transcriptase inhibitors. Antibodies are also being considered (Selhorst et al., 2011). A major drawback of current microbicide clinical trials is that efficacy is only tested in heterosexual woman, not in high risk MSM where the majority of new infections occur in the US (Abdool Karim et al., 2010; Krakower and Mayer, 2011; Prejean et al., 2011).

Male circumcision (MC) has been recognized fairly recently as a potential preventive measure, but its overall impact may depend on the target population. Multiple trials in Africa have shown efficacy of MC in reducing HIV acquisition in heterosexual men by $38-66 \%$, with uncircumcised men showing an 4-fold higher infection risk in sub-Saharan Africa (Siegfried et al., 2009; Gebremedhin, 2010; Wamai et al., 2011) (Table 5). However, the impact of MC for MSM is unknown (Smith et al., 2010), as is the overall population of MSM in subSaharan Africa. It has been estimated that HIV transmission among MSM accounts for $0.6-16 \%$ of infections, depending on the country (Wamai et al., 2011). Newer data suggest that MC among MSM in the US, where the overall prevalence of MC already ranges from 43 to $80 \%$, would be of limited benefit (Gust et al., 2010; Jozkowski et al., 2010; Smith et al., 
Table 5 | Selected clinical trials of male circumcision.

\begin{tabular}{|c|c|c|c|c|c|c|}
\hline $\begin{array}{l}\text { Male } \\
\text { circumcision }\end{array}$ & Status & Phase & $\begin{array}{l}\text { Target } \\
\text { group }\end{array}$ & $\begin{array}{l}\text { Alternate } \\
\text { study ID }\end{array}$ & Observation & References \\
\hline NCT00124878 & Unknown & III & Men & 22006 & $\begin{array}{l}\text { No reduction of HIV } \\
\text { transmission to } \\
\text { female partners }\end{array}$ & $\begin{array}{l}\text { Wamai et al., } \\
2011\end{array}$ \\
\hline NCT00425984 & Complete & III & Men & U1Al171-1-02 & $55 \%$ efficacy & Gray et al., 2007 \\
\hline
\end{tabular}

More information about the individual trials can be found using the NCT number and the following databases: www.aidsinfo.nih.gov/clinical-trials; www.clinicaltrials.gov; http://www.avac.org.

2010; Wei et al., 2011). A protective effect was seen in a subgroup of MSM reporting an insertive role, but overall, in 21 observational studies with 71,693 MSM participants, MC did not prevent HIV transmission (Wiysonge et al., 2011), probably because it has no effect on transmission through receptive anal intercourse.

Other alternatives for prevention or cure are targeting the CCR5 receptor as well as the latent HIV reservoir. With regard to the former, the idea of modulating the expression of CCR5 on CD4 T-cells is not new and CCR5 blocking molecules are used in the clinic (e.g., Maraviroc) or have been investigated in animal models or clinical trials (e.g., TAK-779, Aplaviroc, and Vicriviroc). However, resistance, lack of efficiency or toxicity has been associated with these compounds (Ryan, 2005; Sax, 2006; Nichols et al., 2008; Ogert et al., 2008; Demarest et al., 2009; Kitrinos et al., 2009; Wilkin et al., 2010). For example, treatment with CCR5 co-receptor antagonists can lead to selection of resistant viruses whose entry rates into target cells in the presence of the antagonist have been restored to wild-type levels (Putcharoen et al., 2011). Nevertheless, interest in targeting the CCR5 co-receptor persists, in part due to the case study of an individual potentially cured of HIV infection after receiving a bone marrow transplant for treatment of acute myeloid leukemia from a donor homozygous for CCR $5 \Delta 32$ (Allers et al., 2011). New approaches include attempts to permanently alter the expression of the CCR5 receptor on CD4 cells by gene therapy (e.g., knockout and knockdown) (Cannon and June, 2011). shRNA knockdown of CCR5 in the humanized mouse model has led to reduced expression on T-cells in the gut mucosa, and splenocytes were harder to infect with HIV (Shimizu et al., 2010). In another experiment, RNA interference-mediated knockdown of CCR5 was stable for 10 days and challenged animals exhibited reduced plasma viral loads and enhanced resistance to infection (Kim et al., 2010). Nevertheless, all interventions have drawbacks. Disadvantages of CCR5 knockout include lower anti-tumor, anti-bacterial and anti-parasitic responses, as shown in animal model studies (Gonzalez-Martin et al., 2011; Olive et al., 2011; Sullivan et al., 2011). In addition, disruptions of the normal control of other infectious diseases may occur. For example, in humans CCR5 deficiency is a risk factor for both early and late clinical manifestations of West Nile virus (Lim et al., 2010) and tickborne encephalitis (Kindberg et al., 2008) infections.
The idea of purging the viral reservoir in order to affect a cure of HIV infection has been a long-term goal (Frater, 2011; Palmer et al., 2011). However, simply intensifying drug regimens has not succeeded despite suppression of viral loads below 1 copy $/ \mathrm{ml}$ plasma (Byakwaga et al., 2011; Dahl et al., 2011). A potential explanation could be on going cell to cell spread of the virus (Sigal et al., 2011). In rare instances upon infection of resting CD4 T-cells HIV goes into latency, a phenomenon known for over 20 years (Bednarik and Folks, 1992). These latent reservoir cells have a long half-life and reactivation leads to reemerging viremia (Iglesias-Ussel and Romerio, 2011; Pace et al., 2011). Mechanisms controlling latency act at the transcriptional level, where hypoacetylation of histones correlates with repression (Lafeuillade and Stevenson, 2011). Histone deacetylase (HDAC) inhibitors, such as Valproic acid (VPA), a known medication for psychiatric disorders, have been tried together with ART to reduce the latent virus reservoir with mixed results and side-effects at higher doses (Lehrman et al., 2005; Margolis, 2011; Matalon et al., 2011; Routy et al., 2012). The development of safer, more efficient HDAC inhibitors in combination with ART might provide a promising path toward a cure for HIV (Margolis, 2011). Other more specific HDAC inhibitors are under development (Matalon et al., 2011). A promising candidate is Givinostat, shown to be safe in humans, and slated to move into clinical phase II trials (Furlan et al., 2011).

\section{VACCINE DEVELOPMENT}

HIV vaccines have been designed for both therapy and prevention. Multiple clinical trials with therapeutic vaccines have been conducted. To mention a few, approaches have included rAd5HIV gag (Li et al., 2011) Tat protein or Tat DNA (Caputo et al., 2009), ALVAC encoding multiple HIV genes plus gp160 (Jin et al., 2002), gp160 protein alone (Kundu-Raychaudhuri et al., 2001; Gudmundsdotter et al., 2008), and dendritic cells (DC) pulsed with autologous inactivated virus (García et al., 2011). The overall outcome in most studies was a temporary significant drop in viral loads, induction of cytotoxic T-cell responses, as well as improved CD4 counts. To date, therapeutic vaccines have not progressed to the point of replacing drug therapy. However, this is an important although challenging goal in view of toxicities associated with drug regimens. A key factor in application of all therapeutic vaccines may be early initiation after infection in order to surmount HIV-associated T- and B-cell dysfunctions. 
Most of the research emphasis in the field is devoted toward the development of a preventive HIV vaccine. A highly efficacious vaccine would circumvent the need for multiple preventive strategies, and would have its greatest impact in countries of the emerging and developing world where treatment availability is still scarce. However, such a vaccine is still elusive (Girard et al., 2011). The clinical trial (RV144) of ALVACHIV recombinant priming followed by gp120 protein boosting (Table 6) (Rerks-Ngarm et al., 2009; Girard et al., 2011) conducted in Thailand showed 31\% efficacy. It has been suggested that in Thailand the RV-144 approach could provide modest long term benefit even without revaccination to combat the short-term effectiveness of the vaccine (Schneider et al., 2011). However, the vaccine approach overall was far from reaching the protective efficacy desired. As outlined below, achieving a more efficacious vaccine will require continuing, major research efforts.

An ideal vaccine should induce long lived memory T-cells with high cytotoxic potential and B-cells able to secrete potent, functional antibodies (Benmira et al., 2010). As T-cell vaccines have been intensively reviewed recently (Ahlers and Belyakov, 2010a,b; Perrin et al., 2010), here we will address B cell immunity. That antibodies alone are sufficient to prevent infection has been clearly shown in passive transfer studies in animal models (Baba et al., 2000; Mascola et al., 2000; Nishimura et al., 2003). Additionally, a recent gene therapy approach using an AAV vector expressing neutralizing antibody conferred protection in non-human primates (Johnson et al., 2009). In addition to the well-known broadly neutralizing antibodies b12, 2G12, 2F5, 4E10, and Z13 (Muster et al., 1993; Burton et al., 1994; Trkola et al., 1996; Zwick et al., 2001) the recent isolation of even more potent broadly neutralizing antibodies from infected patients, including VRC-01, -02, and -03; PG9, PG16, 3BNC117, NIH45-46, PGT121-123, and PGT125-128 (Walker et al., 2009, 2011; Wu et al., 2010; Scheid et al., 2011), shows that the immune system is capable of producing these highly sought antibodies. However, no vaccine approach has been able to elicit them, due in part to the complex structure of the HIV (and SIV) envelope

Table 6 | Selected clinical trials of HIV prophylactic vaccines.

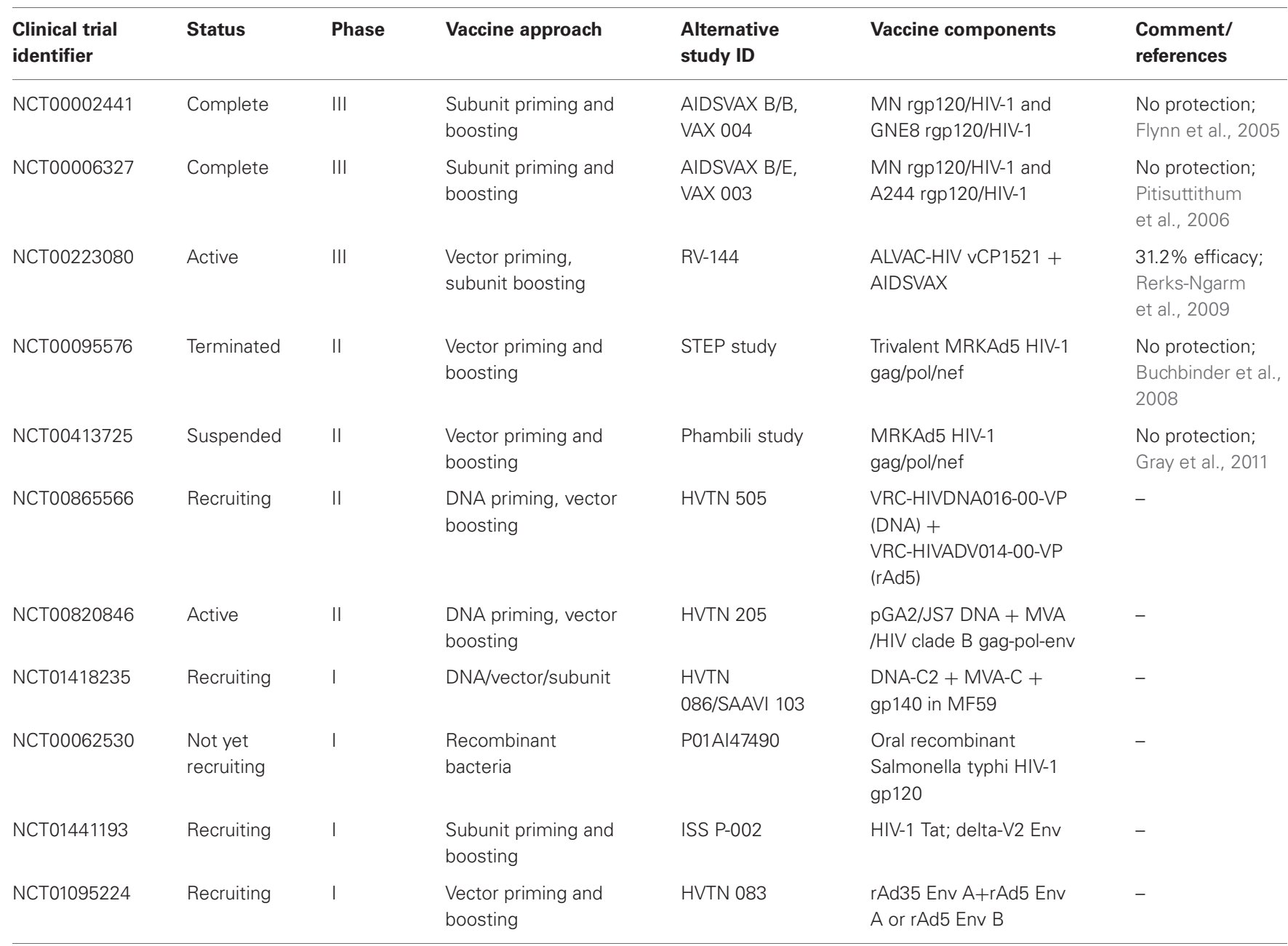

More information about the individual trials can be found using the NCT number and the following databases: www.aidsinfo.nih.gov/clinical-trials; www.clinicaltrials.gov; http://www.avac.org. 
(Roux and Taylor, 2007; Schief et al., 2009; Harris et al., 2011; White et al., 2011). Additionally, the HIV envelope has shown poor binding to germline predecessors of broadly neutralizing antibodies, suggesting a mechanism by which HIV may evade immune responses (Xiao et al., 2009; Chen et al., 2012). In fact, although examination of VRC-01-like antibodies revealed a common pathway of maturation, extensive affinity maturation steps were required to attain broad reactivity (Zhou et al., 2010; Scheid et al., 2011; Wu et al., 2011). Overall, up to 30\% of HIV infected individuals develop cross-reactive neutralizing antibodies approximately 3 years after seroconversion, suggesting that the antibodies need multiple rounds of somatic hypermutation and affinity maturation to achieve broad reactivity and that current recombinant envelope immunogens are unable to promote this process from precursor naïve B-cells (Euler et al., 2012).

Reverse vaccinology and structure-based vaccine design approaches focused on known neutralizing antibody targeted envelope epitopes are attempting to develop vaccine immunogens able to elicit the desired neutralizing antibody potency and breadth (Pejchal and Wilson, 2010; Walker and Burton, 2010). One approach to achieve presentation of critical conformational epitopes is stabilization of the CD4-mediated conformational change in the envelope using a single-chain analogue of the HIV gp120-CD4 complex (DeVico et al., 2007). Other approaches as reviewed in Kwong et al. (2011) and Walker and Burton (2010) include virus like particles, soluble trimers, stabilized envelope trimers with deletion of the gp41 transmembrane domain, conformational stabilization of the Env core protein, generation of envelope subdomains (e.g., the outer domain containing the CD4 attachment site), and employment of scaffolds based on informatics and epitope transplantation (e.g., adding the conserved $\beta 15$ loop of the CD4 binding site to an unrelated structure to present the epitope in its natural configuration). Stable trimers are now available and maintain native conformation (Harris et al., 2011; Lewis et al., 2011; Sellhorn et al., 2011). However, overall envelope glycosylation and the resulting glycan shield can still influence immunogenicity (Benjouad et al., 1992; Kumar et al., 2011) and remains a problem for vaccine development and design (Kwong et al., 2011).

The variable loop regions (V1/V2 and V3) of the viral envelope have regained attention, due to their interaction with the guthoming $\alpha 4 \beta 7$ receptor (Arthos et al., 2008), role in viral transmission, binding to highly potent neutralizing antibodies (Doores and Burton, 2010; Collins-Fairclough et al., 2011; Pejchal et al., 2011) and recent correlation with reduced risk of HIV infection in the RV144 trial (Zolla-Pazner et al., 2011a). As a result, scaffolds that present V1-V2 in the appropriate native conformation are currently under study. However, during HIV infection, V1-V2 loop sequences expand and add glycosylation sites, which in turn could affect binding and neutralization by antibodies (Sagar et al., 2006). The V3 loop, long-thought to elicit only type-specific antibodies, has some structurally conserved elements (Carrow et al., 1991; Boudet et al., 1992; Almond et al., 2010; Jiang et al., 2010), suggesting a potential for inducing broadly neutralizing antibodies. Recently, a V3 scaffold immunogen based on structure-guided design elicited cross-clade neutralizing antibodies in rabbits (Totrov et al., 2010; Zolla-Pazner et al., 2011b), raising hope that similar constructs would be equally effective in humans. Nevertheless, structural approaches and reverse engineering still face multiple obstacles and limitations from numerous extrinsic factors such as the host immunoglobulin gene repertoire and cellular regulatory mechanisms in the immunized host during antigen processing and antibody affinity maturation (Van Regenmortel, 2011, 2012). Additional limitations are imposed by discontinuous epitopes that are difficult to isolate in their native tertiary structure, and quaternary structure which introduces transient, conformational "neotopes" and masked "cryptotopes" which appear only in the context of the assembled virus particle (Van Regenmortel, 2011, 2012). Cross-reactivity or heterospecificity arising from weak antigen B-cell receptor interactions can also potentially lead to auto reactive antibodies as reported for 2F5 and 4E10 (Haynes et al., 2005). Understanding the complex interactions between antigen presenting cells (APC) and B-cells at different mucosal sites or in lymph nodes is important for designing optimal vaccine approaches. The HIV envelope in particular is poorly immunogenic. It can suppress CD4 T-cell activation and proliferation (Fernando et al., 2007) and can mediate T-cell apoptosis (Arthos et al., 2002). Further, high affinity antibodies recognizing the CD4-binding site can skew MHC class II presentation by partially obstructing antigen processing, leading to decreased anti-gp120 T helper responses (Tuen et al., 2005). It is crucial to find measures to boost the envelope's immunogenicity in order to elicit potent and durable anti-env responses. The contributions of cells of the innate immune system, such as NK, NKT, $\gamma \delta$ T-cells, and DC are under extensive investigation (Bostik et al., 2010; Palucka et al., 2010; Agrati et al., 2011; Altfeld et al., 2011; Padte et al., 2011; Ansari et al., 2012). Cross-talk between the innate and adaptive immune systems is important in shaping adaptive B-cell responses (Cerutti et al., 2011). Innate programming of protective immunity in general and programming of antibody (and $\mathrm{T}$ cell) responses by innate immune components have recently been reviewed (Pulendran and Ahmed, 2011).

Apart from design of specific vaccine components and regimens, the route of administration can influence immune response elicitation, systemically and mucosally at genital/rectal sites (Demberg and Robert-Guroff, 2009; Mestecky et al., 2010). Vectored vaccines can be administered by a variety of routes and in addition to eliciting $\mathrm{T}$ cell responses also effectively induce humoral immunity. Prominent vectors currently in use are replication competent or defective Adenoviruses, Canarypox (ALVAC), and Vaccinia (NYVAC, MVA) (Franchini et al., 2004; Gomez et al., 2008; Patterson and Robert-Guroff, 2008; Barouch, 2010; Chen et al., 2010; Rollier et al., 2011; Weli and Tryland, 2011). Adenoviruses, by targeting mucosal epithelium, induce mucosal as well as systemic immunity. In fact, replicationcompetent Adenovirus vectors display a broad biodistribution. Regardless of mucosal immunization route, they target and persist in macrophages and myeloid dendritic cells (Patterson et al., 2012) and elicit comparable immune responses systemically and mucosally (Xiao et al., 2012). An interesting approach is the use of recombinant Cytomegalovirus (CMV) vectors. 
These recombinants also persist in the host and stimulate strong CD4 and CD8 cell responses (Hansen et al., 2011). Using rhesus CMV vectors expressing SIV transgenes, strong protection from acquisition of $\operatorname{SIV}_{\text {mac239 }}$ was achieved in a rectal low-dose challenge model (Hansen et al., 2011). In spite of the impressive protection in rhesus macaques, translation into the clinic may present a challenge due to the significant morbidity that can be caused by reoccurring CMV infection, seen for example, in immunosuppressed individuals (Sellar and Peggs, 2012). Other vectors targeting the mucosa include integrase-defective lentiviruses (Negri et al., 2011), noroviruses (Herbst-Kralovetz et al., 2010) and engineered bacteria such as Listeria, Salmonella, Lactococcus, and Lactobacillus (Shahabi et al., 2010; Bahey-El-Din and Gahan, 2011; Lagenaur et al., 2011).

DNA vaccines alone can also successfully prime and boost the immune system (Ferraro et al., 2011; Sardesai and Weiner, 2011) and together with viral vectors have induced lasting immune responses and long-term control of virus infection following challenge of non-human primates (Patel et al., 2010; Lai et al., 2011; Manrique et al., 2011; Winstone et al., 2011). Electroporation, instead of intramuscular injection of DNA, has enhanced development of durable immunity (Patel et al., 2010). Moreover, use of DNA vaccines facilitates incorporation of cytokine immune modulators (IL-15, IL-12, GM-CSF, and TNF- $\alpha$ ) into the vaccine strategy (Demberg et al., 2008; Ferraro et al., 2011; Lai et al., 2011; Manrique et al., 2011; Winstone et al., 2011).

Vectored vaccines are often combined with envelope protein boosts, requiring an adjuvant. Cytokines and TLR ligands can serve this purpose (Berzofsky et al., 2001; Tovey and Lallemand, 2010; Bode et al., 2011; Duthie et al., 2011) but traditionally, adjuvants function as depots while also acting as immunostimulants (Reed et al., 2009; Carter and Reed, 2010). Currently there are only two adjuvants in licensed vaccines available in the USA: aluminum salts, including aluminum hydroxide, aluminum phosphate and alum (potassium aluminum sulfate); and AS04 (aluminum hydroxide combined with monophosphoryl lipid (http://www.fda.gov/BiologicsBloodVaccines/Safety Availability/VaccineSafety/ucm187810.htm). In Europe, additional approved adjuvants include MF59 (squalene-based oil in water emulsion) and AS03 (also squalene-based) (Tritto et al., 2009; Carter and Reed, 2010; O'Hagan et al., 2011). Yet additional adjuvants are needed. Broad new candidates include carbohydrate-based and saponin based compounds, ISCOM Matrix, cationic liposomes, and Nano-microparticles (Oyewumi et al., 2010; Christensen et al., 2011; Lovgren Bengtsson et al., 2011; Petrovsky and Cooper, 2011; Ragupathi et al., 2011; Schijns and Lavelle, 2011).

A crucial aspect for the evaluation of candidate vaccines is availability of relevant animal models. Currently there are only two appropriate models: non-human primates and the newly developed bone marrow/liver/thymus (BLT) mouse model. The BLT mouse develops human T cells and B cells, monocyte/macrophages and DC (Wege et al., 2008). In this model HIV latency has been described and thus the BLT mouse is suitable for testing drug regimens, including evaluation of HDAC inhibitors (Marsden et al., 2011). Due to the reconstitution of the female
BLT mouse reproductive tract with human immune cells, vaginal challenges can be performed and microbicides can be evaluated (Denton et al., 2011; Olesen et al., 2011). In addition, candidate vaccines based on non-replicating vectors as well as novel adjuvants can be tested in a shorter time frame and at lower cost compared to non-human primate models (Biswas et al., 2011). However, the BLT mouse model has its limitations, including lack of proper T-cell help which affects development of humoral responses (Biswas et al., 2011).

Overall non-human primates provide the best, although not perfect, model for evaluation of pre-clinical candidate vaccines (Morgan et al., 2008; Rompay, 2011). The SIV rhesus macaque system appropriately models HIV disease of humans with regard to mode of transmission, viremia levels, depletion of CD4 cells, and development of AIDS. However, the difference in the SIV and HIV envelopes does not allow evaluation of anti-HIV envelope immunity in the SIV system. The SHIV model while not as robust, allows evaluation of vaccines targeting the HIV envelope and their ability to elicit sterilizing immunity, however, it is generally poorly pathogenic and overall a poor model of HIV biology and disease progression in humans. Further, experiments in non-human primates are expensive, and the number of macaques required for a pre-clinical vaccine study has increased with the use of low-dose repeated challenge experiments that better mimic the HIV infection of people (Keele et al., 2009). Thus, evaluation of a single vaccine candidate and a control could require 50 macaques (Hudgens and Gilbert, 2009), However, it could be designed and completed quickly. The cost for such a macaque study is far surpassed by that of a human clinical trial. As summarized by Shedlock et al. (2009), the non-human primate model has a key role to play in evaluating vaccine candidates for the ability to induce improved immune responses, in testing hypothesis driven research, in providing proof of concept, and in identifying new immune targets for incorporation into vaccine design. In that way the model helps select vaccine candidates for advancement into the limited number of possible clinical trials.

\section{SUMMARY AND CONCLUSION}

As briefly summarized by this review the substantial progress made in AIDS treatment has stimulated the concept of "treatment as prevention." Additionally, vaccine development has picked up momentum due to new discoveries and the modest success of the RV144 clinical trial in Thailand. However, to achieve global control of HIV/AIDS infection in the absence of a highly efficacious vaccine or cure, a combination of multiple preventive measures will need to be continuously applied. Further investigation of all elements of the host immune system, both innate and adaptive, as well as development of novel treatment strategies should proceed in order to insure strong control of the AIDS pandemic and eventual eradication of the disease.

\section{ACKNOWLEDGMENTS}

We thank L. Jean Patterson and Janet DiPasquale for critical comments and reading of the manuscript. This work was supported by the Intramural Research Program of the National Institutes of Health, National Cancer Institute. 


\section{REFERENCES}

Abdool Karim, Q., Abdool Karim, S. S., Frohlich, J. A., Grobler, A. C., Baxter, C., Mansoor, L. E., Kharsany, A. B., Sibeko, S., Mlisana, K. P., Omar, Z., Gengiah, T. N., Maarschalk, S., Arulappan, N., Mlotshwa, M., Morris, L., and Taylor, D. (2010). Effectiveness and safety of tenofovir gel, an antiretroviral microbicide, for the prevention of HIV infection in women. Science $329,1168-1174$.

Abdool Karim, S. S., Richardson, B. A., Ramjee, G., Hoffman, I. F., Chirenje, Z. M., Taha, T., Kapina, M., Maslankowski, L., Coletti, A., Profy, A., Moench, T. R., PiwowarManning, E., Masse, B., Hillier, S. L., and Soto-Torres, L. (2011). Safety and effectiveness of BufferGel and $0.5 \%$ PRO2000 gel for the prevention of HIV infection in women. AIDS 25, 957-966.

Adimora, A. A., and Auerbach, J. D. (2010). Structural interventions for HIV prevention in the United States. J. Acquir. Immune. Defic. Syndr. 55, S132-S135.

Agrati, C., D'Offizi, G., Gougeon, M. L., Malkovsky, M., Sacchi, A., Casetti, R., Bordoni, V., Cimini, E., and Martini, F. (2011). Innate gamma/delta T-cells during HIV infection: Terra relatively Incognita in novel vaccination strategies? AIDS Rev. 13, 3-12.

Ahlers, J. D., and Belyakov, I. M. (2010a). Lessons learned from natural infection: focusing on the design of protective $\mathrm{T}$ cell vaccines for HIV/AIDS. Trends Immunol. 31, 120-130.

Ahlers, J. D., and Belyakov, I. M. (2010b). Memories that last forever: strategies for optimizing vaccine Tcell memory. Blood 115, 1678-1689.

Allers, K., Hutter, G., Hofmann, J., Loddenkemper, C., Rieger, K., Thiel, E., and Schneider, T. (2011). Evidence for the cure of HIV infection by CCR5Delta32/Delta32 stem cell transplantation. Blood 117, 2791-2799.

Almond, D., Kimura, T., Kong, X., Swetnam, J., Zolla-Pazner, S., and Cardozo, T. (2010). Structural conservation predominates over sequence variability in the crown of HIV type 1's V3 loop. AIDS Res. Hum. Retroviruses 26, 717-723.

Altfeld, M., Fadda, L., Frleta, D., and Bhardwaj, N. (2011). DCs and NK cells: critical effectors in the immune response to HIV-1. Nat. Rev. Immunol. 11, 176-186.

Ambrose, Z., Compton, L., Piatak, M. Jr. Lu, D., Alvord, W. G., Lubomirski, M. S., Hildreth, J.
E., Lifson, J. D., Miller, C. J., and Kewalramani, V. N. (2008). Incomplete protection against simian immunodeficiency virus vaginal transmission in rhesus macaques by a topical antiviral agent revealed by repeat challenges. J. Virol. 82, 6591-6599.

Amuri, M., Mitchell, S., Cockcroft, A., and Andersson, N. (2011). Socioeconomic status and HIV/AIDS stigma in Tanzania. AIDS Care 23, 378-382.

Ansari, A. A., Mayne, A. E., Takahashi, Y., and Pattanapanyasat, K. (2012). Incorporation of innate immune effector mechanisms in the formulation of a vaccine against HIV-1. Adv. Exp. Med. Biol. 780, 143-159.

Arthos, J., Cicala, C., Martinelli, E., Macleod, K., Van Ryk, D., Wei, D., Xiao, Z., Veenstra, T. D., Conrad, T. P., Lempicki, R. A., McLaughlin, S., Pascuccio, M., Gopaul, R., McNally, J., Cruz, C. C., Censoplano, N., Chung, E., Reitano, K. N., Kottilil, S., Goode, D. J., and Fauci, A. S. (2008). HIV-1 envelope protein binds to and signals through integrin alpha4beta7, the gut mucosal homing receptor for peripheral $\mathrm{T}$ cells. Nat. Immunol. 9, 301-309.

Arthos, J., Cicala, C., Selig, S. M., White, A. A., Ravindranath, $\mathrm{H}$ M., Van Ryk, D., Steenbeke, T. D., Machado, E., Khazanie, P., Hanback, M. S., Hanback, D. B., Rabin, R. L., and Fauci, A. S. (2002). The role of the CD4 receptor versus HIV coreceptors in envelopemediated apoptosis in peripheral blood mononuclear cells. Virology 292, 98-106.

Auvert, B., Taljaard, D., Lagarde, E. Sobngwi-Tambekou, J., Sitta, R., and Puren, A. (2005). Randomized, controlled intervention trial of male circumcision for reduction of HIV infection risk: the ANRS (1265). PLoS Med. 2:e298. doi: 10.1371/journal.pmed.0020298

Baba, T. W., Liska, V., HofmannLehmann, R., Vlasak, J., Xu, W., Ayehunie, S., Cavacini, L. A., Posner, M. R., Katinger, H., Stiegler, G., Bernacky, B. J., Rizvi, T. A., Schnidt, R., Hill, L. R., Keeling, M. E., Lu, Y., Wright, J. E., Chou, T., and Ruprecht, R. M. (2000). Human neutralizing monoclonal antibodies of the IgGlsubtype protect against mucosal simian-human immunodeficiency virus infection. Nat. Med. 6, 200-206.

Bahey-El-Din, M., and Gahan, C. G. (2011). Lactococcus lactis-based vaccines: current status and future perspectives. Hum. Vaccin. 7, 106-109.
Barber, D. L., Andrade, B. B., Sereti, I. and Sher, A. (2012). Immune reconstitution inflammatory syndrome: the trouble with immunity when you had none. Nat. Rev. Microbiol. $10,150-156$.

Barouch, D. H. (2010). Novel adenovirus vector-based vaccines for HIV-1. Curr. Opin. HIV AIDS 5, 386-390.

Bastard, J. P., Soulié, C., Fellahi, S., Haïm-Boukobza, S., Simon, A., Katlama, C., Calvez, V., Marcelin, A. G., and Capeau, J. (2012). Circulating interleukin6 levels correlate with residual HIV viraemia and markers of immune dysfunction in treatmentcontrolled HIV-infected patients. Antivir. Ther. doi: 10.3851/ IMP2093. [Epub ahead of print].

Beauliere, A., Toure, S., Alexandre, P. K., Kone, K., Pouhe, A., Kouadio, B., Journy, N., Son, J., EttiegneTraore, V., Dabis, F., Eholie, S. and Anglaret, X. (2010). The financial burden of morbidity in HIV-infected adults on antiretroviral therapy in Cote d'Ivoire. PLOS ONE 5:e11213. doi: 10.1371/ journal.pone.0011213

Bednarik, D. P., and Folks, T. M. (1992). Mechanisms of HIV-1 latency. AIDS 6, 3-16.

Begay, O., Jean-Pierre, N., Abraham, C. J., Chudolij, A., Seidor, S. Rodriguez, A., Ford, B. E. Henderson, M., Katz, D., Zydowsky, T., Robbiani, M., and FernandezRomero, J. A. (2011). Identification of personal lubricants that can cause rectal epithelial cell damage and enhance HIV type 1 replication in vitro. AIDS Res. Hum. Retroviruses 27, 1019-1024.

Benjouad, A., Gluckman, J. C., Rochat, H., Montagnier, L., and Bahraoui, E. (1992). Influence of carbohydrate moieties on the immunogenicity of human immunodeficiency virus type 1 recombinant gp160. J. Virol. 66, 2473-2483.

Benmira, S., Bhattacharya, V., and Schmid, M. L. (2010). An effective HIV vaccine: a combination of humoral and cellular immunity? Curr. HIV Res. 8, 441-449.

Berzofsky, J. A., Ahlers, J. D., and Belyakov, I. M. (2001). Strategies for designing and optimizing new generation vaccines. Nat. Rev. Immunol. 1, 209-219.

Birbeck, G. L., Kvalsund, M. P., Byers, P. A., Bradbury, R., Mang'ombe, C., Organek, N., Kaile, T., Sinyama, A. M., Sinyangwe, S. S., Malama, K., and Malama, C. (2011). Neuropsychiatric and socioeconomic status impact antiretroviral adherence and mortality in rural Zambia. Am. J. Trop. Med. Hyg. 85, 782-789.

Biswas, S., Chang, H., Sarkis, P. T., Fikrig, E., Zhu, Q., and Marasco, W. A. (2011). Humoral immune responses in humanized BLT mice immunized with West Nile virus and HIV-1 envelope proteins are largely mediated via human $\mathrm{CD} 5(+)$ B cells. Immunology 134, 419-433.

Bode, C., Zhao, G., Steinhagen, F., Kinjo, T., and Klinman, D. M. (2011). CpG DNA as a vaccine adjuvant. Expert Rev. Vaccines 10, 499-511.

Boesecke, C., and Vogel, M. (2011). HIV and hepatitis C co-infection: acute HCV therapy. Curr. Opin. HIV AIDS 6, 459-464.

Bostik, P., Takahashi, Y., Mayne, A. E., and Ansari, A. A. (2010). Innate immune natural killer cells and their role in HIV and SIV infection. HIV Ther. 4, 483-504.

Boudet, F., Girard, M., Theze, J., and Zouali, M. (1992). Antibodies of HIV-1 positive subjects and experimentally immunized primates and rodents bind to sequence divergent regions of the third variable domain (V3) of gp120. Int. Immunol. 4, 283-294.

Broder, S. (2010). The development of antiretroviral therapy and its impact on the HIV-1/AIDS pandemic. Antiviral. Res. 85, 1-18.

Buchbinder, S. P., Mehrotra, D. V., Duerr, A., Fitzgerald, D. W., Mogg, R., Li, D., Gilbert, P. B., Lama, J. R. Marmor, M., Del Rio, C., McElrath, M. J., Casimiro, D. R., Gottesdiener, K. M., Chodakewitz, J. A., Corey, L., and Robertson, M. N. (2008). Efficacy assessment of a cellmediated immunity HIV-1 vaccine (the Step Study): a double-blind, randomised, placebo-controlled, test-of-concept trial. Lancet 372, 1881-1893.

Burton, D. R., Pyati, J., Koduri, R. Sharp, S. J., Thornton, G. B., Parren, P. W., Sawyer, L. S., Hendry, R. M., Dunlop, N., Nara, P. L., Lamacchia, M., Garratty, E., Stiehm, E. R., Bryson, Y. J., Cao, Y., Moore, J. P., Ho, D. D., and Barbas, C. F. III. (1994). Efficient neutralization of primary isolates of HIV-1 by a recombinant human monoclonal antibody. Science 266, 1024-1027.

Byakwaga, H., Kelly, M., Purcell, D. F. French, M. A., Amin, J., Lewin, S. R., Haskelberg, H., Kelleher, A. D., Garsia, R., Boyd, M. A., Cooper, D. A., and Emery, S. (2011). Intensification of antiretroviral therapy with raltegravir or addition of hyperimmune bovine colostrum 
in HIV-infected patients with suboptimal CD4+ T-cell response: a randomized controlled trial. J. Infect. Dis. 204, 1532-1540.

Cannon, P., and June, C. (2011). Chemokine receptor 5 knockout strategies. Curr. Opin. HIV AIDS 6, 74-79.

Caputo, A., Gavioli, R., Bellino, S., Longo, O., Tripiciano, A., Francavilla, V., Sgadari, C., Paniccia, G., Titti, F., Cafaro, A., Ferrantelli, F., Monini, P., Ensoli, F., and Ensoli, B. (2009). HIV-1 Tat-based vaccines: an overview and perspectives in the field of HIV/AIDS vaccine development. Int. Rev. Immunol. 28, 285-334.

Carbone, A., Gloghini, A., Serraino, D., and Spina, M. (2009). HIVassociated Hodgkin lymphoma. Curr. Opin. HIV AIDS 4, 3-10.

Carr, J. K., Osinusi, A., Flynn, C. P., Gilliam, B. L., Maheshwari, V., and Zhao, R. Y. (2010). Two independent epidemics of HIV in Maryland. J. Acquir. Immune. Defic. Syndr. 54, 297-303.

Carrow, E. W., Vujcic, L. K., Glass, W. L., Seamon, K. B., Rastogi, S. C., Hendry, R. M., Boulos, R., Nzila, N., and Quinnan, G. V. Jr. (1991). High prevalence of antibodies to the gp120 V3 region principal neutralizing determinant of HIV-1MN in sera from Africa and the Americas. AIDS Res. Hum. Retroviruses 7, 831-838.

Carter, D., and Reed, S. G. (2010). Role of adjuvants in modeling the immune response. Curr. Opin. HIV AIDS 5, 409-413.

Carvalho, F. T., Gonçalves, T. R., Faria, E. R., Shoveller, J. A., Piccinini, C. A., Ramos, M. C., and Medeiros, L. R. (2011). Behavioral interventions to promote condom use among women living with HIV. Cochrane Database Syst. Rev. CD007844.

Cerutti, A., Puga, I., and Cols, M. (2011). Innate control of B cell responses. Trends Immunol. 32, 202-211.

Chamberland, A., Diabate, S., Sylla, M., Anagounou, S., Geraldo, N., Zannou, D. M., Labbe, A. C., Worobey, M., Alary, M., and Tremblay, C. (2011). Transmission of HIV-1 drug resistance in Benin could jeopardise future treatment options. Sex Transm. Infect. 88, 179-183.

Chen, H., Xiang, Z. Q., Li, Y., Kurupati, R. K., Jia, B., Bian, A., Zhou, D. M., Hutnick, N., Yuan, S., Gray, C., Serwanga, J., Auma, B., Kaleebu, P., Zhou, X., Betts, M. R., and Ertl, H. C. (2010). Adenovirus-based vaccines: comparison of vectors from three species of adenoviridae. J. Virol. 84, 10522-10532.

Chen, W., Streaker, E. D., Russ, D. E., Feng, Y., Prabakaran, P., and Dimitrov, D. S. (2012). Characterization of germline antibody libraries from human umbilical cord blood and selection of monoclonal antibodies to viral envelope glycoproteins: implications for mechanisms of immune evasion and design of vaccine immunogens. Biochem. Biophys. Res. Commun. 417, 1164-1169.

Chesson, H. W., Gift, T. L., OwusuEdusei, K. Jr., Tao, G., Johnson, A. P., and Kent, C. K. (2011). A brief review of the estimated economic burden of sexually transmitted diseases in the United States: inflation-adjusted updates of previously published cost studies. Sex Transm. Dis. 38, 889-891.

Chong, Y., Ikematsu, H., Kikuchi, K., Yamamoto, M., Murata, M., Nishimura, M., Nabeshima, S., Kashiwagi, S., and Hayashi, J. (2004). Selective CD27+ (memory) $\mathrm{B}$ cell reduction and characteristic $B$ cell alteration in drug-naive and HAART-treated HIV type 1-infected patients. AIDS Res. Hum. Retroviruses 20, 219-226.

Christensen, D., Korsholm, K. S. Andersen, P., and Agger, E. M. (2011). Cationic liposomes as vaccine adjuvants. Expert Rev. Vaccines $10,513-521$.

Cohen, M. S., Chen, Y. Q., McCauley, M., Gamble, T., Hosseinipour, M. C., Kumarasamy, N., Hakim, J. G., Kumwenda, J., Grinsztejn, B., Pilotto, J. H. S., Godbole, S. V., Mehendale, S., Chariyalertsak, S., Santos, B. R., Mayer, K. H., Hoffman, I. F., Eshleman, S. H., Piwowar-Manning, E., Wang, L., Makhema, J., Mills, L. A., de Bruyn, G., Sanne, I., Eron, J., Gallant, J., Havlir, D., Swindells, S., Ribaudo, H., Elharrar, V., Burns, D., Taha, T. E., Nielsen-Saines, K., Celentano, D., Essex, M., and Fleming, T. R., for the HPTN 052 Study Team. (2011). Prevention of HIV-1 infection with early antiretroviral therapy. $N$. Eng. J. Med. 365, 493-505.

Collins-Fairclough, A. M., Charurat, M., Nadai, Y., Pando, M., Avila, M. M., Blattner, W. A., and Carr, J. K. (2011). Significantly longer envelope V2 loops are characteristic of heterosexually transmitted subtype B HIV-1 in Trinidad. PLoS ONE 6:e19995. doi: 10.1371/journal.pone.0019995

Colombo, G. L., Colangeli, V., Di Biagio, A., Di Matteo, S.,
Viscoli, C., and Viale, P. (2011). Cost-effectiveness analysis of initial HIV treatment under Italian guidelines. Clinicoecon Outcomes Res. 3 , 197-205.

Dahl, V., Lee, E., Peterson, J., Spudich, S. S., Leppla, I., Sinclair, E., Fuchs, D., Palmer, S., and Price, R. W. (2011). Raltegravir treatment intensification does not alter cerebrospinal fluid HIV-1 infection or immunoactivation in subjects on suppressive therapy. J. Infect. Dis. 204, 1936-1945.

Dang, B. N., Giordano, T. P., and Kim, J. H. (2011). Sociocultural and structural barriers to care among undocumented Latino immigrants with HIV infection. J. Immigr. Minor. Health 14, 124-131.

Demarest, J. F., Amrine-Madsen, H., Irlbeck, D. M., and Kitrinos, K. M. (2009). Virologic failure in first-line human immunodeficiency virus therapy with a CCR5 entry inhibitor, aplaviroc, plus a fixed-dose combination of lamivudine-zidovudine: nucleoside reverse transcriptase inhibitor resistance regardless of envelope tropism. Antimicrob. Agents Chemother. 53, 1116-1123.

Demberg, T., Boyer, J. D., Malkevich, N., Patterson, L. J., Venzon, D., Summers, E. L., Kalisz, I., Kalyanaraman, V. S., Lee, E. M. Weiner, D. B., and Robert-Guroff, M. (2008). Sequential priming with simian immunodeficiency virus (SIV) DNA vaccines, with or without encoded cytokines, and a replicating adenovirus-SIV recombinant followed by protein boosting does not control a pathogenic SIVmac251 mucosal challenge. J. Virol. 82, 10911-10921.

Demberg, T., and Robert-Guroff, $\mathrm{M}$ (2009). Mucosal immunity and protection against HIV/SIV infection: strategies and challenges for vaccine design. Int. Rev. Immunol. 28 20-48.

Denton, P. W., Othieno, F., MartinezTorres, F., Zou, W., Krisko, J. F., Fleming, E., Zein, S., Powell, D. A., Wahl, A., Kwak, Y. T., Welch, B. D., Kay, M. S., Payne, D. A., Gallay, P., Appella, E., Estes, J. D. Lu, M., and Garcia, J. V. (2011) One percent tenofovir applied topically to humanized BLT mice and used according to the CAPRISA 004 experimental design demonstrates partial protection from vaginal HIV infection, validating the BLT model for evaluation of new microbicide candidates. J. Virol. 85, 7582-7593.

D’Ettorre, G., Paiardini, M., Ceccarelli, G., Silvestri, G., and Vullo, V.
(2011). HIV-associated immune activation: from bench to bedside. AIDS Res. Hum. Retroviruses 27, 355-364.

DeVico, A., Fouts, T., Lewis, G. K., Gallo, R. C., Godfrey, K., Charurat, M., Harris, I., Galmin, L., and Pal, R. (2007). Antibodies to CD4-induced sites in HIV gp120 correlate with the control of SHIV challenge in macaques vaccinated with subunit immunogens. Proc. Natl. Acad. Sci. U.S.A. 104, 17477-17482.

Dolling, D., Phillips, A., Delpech, V., Pillay, D., Cane, P., Crook, A., Shepherd, J., Fearnhill, E., Hill, T., Dunn, D., On Behalf of The UK HIV Drug Resistance Database, and The UK Collaborative HIV Cohort (UK CHIC) Study. (2011). Evaluating the extent of potential resistance to pre-exposure prophylaxis within the UK HIV-1infectious population of men who have sex with men. HIV Med. 13, 309-314.

Doores, K. J., and Burton, D. R. (2010). Variable loop glycan dependency of the broad and potent HIV-1neutralizing antibodies PG9 and PG16. J. Virol. 84, 10510-10521.

Duthie, M. S., Windish, H. P., Fox, C. B., and Reed, S. G. (2011). Use of defined TLR ligands as adjuvants within human vaccines. Immunol. Rev. 239, 178-196.

East, L., Jackson, D., O'Brien, L., and Peters, K. (2011). Condom negotiation: experiences of sexually active young women. J. Adv. Nurs. 67, 77-85.

El-Bassel, N., Gilbert, L., Witte, S., Wu, E., and Chang, M. (2011). Intimate partner violence and HIV among drug-involved women: contexts linking these two epidemicschallenges and implications for prevention and treatment. Subst. Use Misuse 46, 295-306.

Epeldegui, M., Vendrame, E., and Martinez-Maza, O. (2010). HIVassociated immune dysfunction and viral infection: role in the pathogenesis of AIDS-related lymphoma. Immunol. Res. 48, 72-83.

Espinoza, L., Hall, H. I., and Hu, X. (2012). Diagnoses of HIV Infection among Hispanics/Latinos in 40 States and Puerto Rico, 2006-2009. J. Acquir. Immune. Defic. Syndr. 60 205-213.

Euler, Z., van den Kerkhof, T. L., van Gils, M. J., Burger, J. A., Edo-Matas, D., Phung, P., Wrin, T., and Schuitemaker, H. (2012). Longitudinal analysis of early HIV1-specific neutralizing activity in an elite neutralizer and in five patients who developed cross-reactive 
neutralizing activity. J. Virol. 86, 2045-2055.

Fair, C. D., and Vanyur, J. (2011). Sexual coercion, verbal aggression, and condom use consistency among college students. J. Am. Coll. Health $59,273-280$

Fernando, K., Hu, H., Ni, H., Hoxie, J. A., and Weissman, D. (2007). Vaccine-delivered HIV envelope inhibits CD4(+) T-cell activation, a mechanism for poor HIV vaccine responses. Blood 109, 2538-2544.

Fernandez-Montero, J. V., Barreiro, P., Del Romero, J., and Soriano, V. (2012). Antiretroviral drugs for preexposure prophylaxis of HIV infection. AIDS Rev. 14, 54-61.

Ferraro, B., Morrow, M. P., Hutnick, N. A., Shin, T. H., Lucke, C. E., and Weiner, D. B. (2011). Clinical applications of DNA vaccines: current progress. Clin. Infect. Dis. 53, 296-302.

Fichtenbaum, C. J. (2010). Does antiretroviral therapy increase or decrease the risk of cardiovascular disease? Curr. HIV/AIDS Rep. 7, 92-98.

Finlayson, T. J., Le, B., Smith, A., Bowles, K., Cribbin, M., Miles, I., Oster, A. M., Martin, T., Edwards, A., and Dinenno, E. (2011). HIV risk, prevention, and testing behaviors among men who have sex with men-National HIV Behavioral Surveillance System, 21 U.S. cities, United States, 2008. MMWR Surveill. Summ. 60, 1-34.

Fleishman, J. A., Yehia, B. R., Moore, R. D., and Gebo, K. A. (2010). The economic burden of late entry into medical care for patients with HIV infection. Med. Care 48, 1071-1079.

Flynn, N. M., Forthal, D. N., Harro, C. D., Judson, F. N., Mayer, K. H., and Para, M. F. (2005). Placebocontrolled phase 3 trial of a recombinant glycoprotein 120 vaccine to prevent HIV-1 infection. J. Infect. Dis. 191, 654-665.

Franchini, G., Gurunathan, S., Baglyos, L., Plotkin, S., and Tartaglia, J. (2004). Poxvirus-based vaccine candidates for HIV: two decades of experience with special emphasis on canarypox vectors. Expert. Rev. Vaccines 3, S75-88.

Frater, J. (2011). New approaches in HIV eradication research. Curr. Opin. Infect. Dis. 24, 593-598.

Furlan, A., Monzani, V., Reznikov, L. L., Leoni, F., Fossati, G., Modena, D., Mascagni, P., and Dinarello, C. A. (2011). Pharmacokinetics, safety and inducible cytokine responses during a phase 1 trial of the oral histone deacetylase inhibitor ITF2357 (givinostat). Mol. Med. 17, 353-362.
Gakumo, C. A., Moneyham, L. D., Enah, C. C., and Childs, G. D. (2011). The moderating effect of sexual pressure on young Urban women's condom use. Res. Nurs. Health 35, 4-14.

García, F., Climent, N., Assoumou, L., Gil, C., González, N., Alcamí, J., León, A., Romeu, J., Dalmau, J., Martínez-Picado, J., Lifson, J., Autran, B., Costagliola, D., Clotet, B., Gatell, J. M., Plana, M., Gallart, T., and DCV2/MANON07- AIDS Vaccine Research Objective Study Group. (2011). A therapeutic dendritic cell-based vaccine for HIV1 infection. J. Infect. Dis. 203, 473-478.

Gebo, K. A., Fleishman, J. A., Conviser, R., Hellinger, J., Hellinger, F. J., Josephs, J. S., Keiser, P., Gaist, P., and Moore, R. D. (2010). Contemporary costs of HIV healthcare in the HAART era. AIDS 24, 2705-2715.

Gebremedhin, S. (2010). Assessment of the protective effect of male circumcision from HIV infection and sexually transmitted diseases: evidence from 18 demographic and health surveys in sub-Saharan Africa. Afr. J. Reprod. Health 14 105-113.

Gervaz, P., Calmy, A., Durmishi, Y., Allal, A. S., and Morel, P. (2011) Squamous cell carcinoma of the anus-an opportunistic cancer in HIV-positive male homosexuals. World J. Gastroenterol. 17, 2987-2991.

Girard, M. P., Osmanov, S., Assossou, O. M., and Kieny, M. P. (2011). Human immunodeficiency virus (HIV) immunopathogenesis and vaccine development: a review. Vaccine 29, 6191-6218.

Golub, S. A., Kowalczyk, W., Weinberger, C. L., and Parsons, J. T. (2010). Preexposure prophylaxis and predicted condom use among high-risk men who have sex with men. J. Acquir. Immune. Defic. Syndr. 54, 548-555.

Gomez, C. E., Najera, J. L., Krupa, M., and Esteban, M. (2008). The poxvirus vectors MVA and NYVAC as gene delivery systems for vaccination against infectious diseases and cancer. Curr. Gene Ther. 8, 97-120.

Gonzalez-Martin, A., Gomez, L. Lustgarten, J., Mira, E., and Manes, S. (2011). Maximal T cell-mediated antitumor responses rely upon CCR5 expression in both CD4(+) and CD8(+) T cells. Cancer Res. 71, 5455-5466.

Grant, R. M., Lama, J. R., Anderson, P. L., McMahan, V., Liu, A. Y., Vargas, L., Goicochea, P., Casapia, M.,
Guanira-Carranza, J. V., RamirezCardich, M. E., Montoya-Herrera O., Fernandez, T., Veloso, V. G. Buchbinder, S. P., Chariyalertsak, S., Schechter, M., Bekker, L. G., Mayer, K. H., Kallas, E. G., Amico, K. R., Mulligan, K., Bushman, L. R., Hance, R. J., Ganoza, C., Defechereux, P., Postle, B., Wang, F., McConnell, J. J., Zheng, J. H., Lee, J., Rooney, J. F., Jaffe, H. S., Martinez, A. I., Burns, D. N., and Glidden, D. V. (2010). Preexposure chemoprophylaxis for HIV prevention in men who have sex with men. $N$. Engl. J. Med. 363, 2587-2599.

Gray, G. E., Allen, M., Moodie, Z. Churchyard, G., Bekker, L. G., Nchabeleng, M., Mlisana, K. Metch, B., De Bruyn, G., Latka, M. H., Roux, S., Mathebula, M. Naicker, N., Ducar, C., Carter, D. K., Puren, A., Eaton, N., McElrath, M. J., Robertson, M., Corey, L., and Kublin, J. G. (2011). Safety and efficacy of the HVTN 503/Phambili study of a clade-B-based HIV-1 vaccine in South Africa: a double-blind, randomised, placebo-controlled test-of-concept phase 2b study. Lancet Infect. Dis. 11, 507-515.

Gray, R. H., Kigozi, G., Serwadda, D. Makumbi, F., Watya, S., Nalugoda, F., Kiwanuka, N., Moulton, L. H., Chaudhary, M. A., Chen, M. Z. Sewankambo, N. K., WabwireMangen, F., Bacon, M. C., Williams, C. F., Opendi, P., Reynolds, S. J. Laeyendecker, O., Quinn, T. C., and Wawer, M. J. (2007). Male circumcision for HIV prevention in men in Rakai, Uganda: a randomised trial. Lancet 369, 657-666.

Greenberg, A. E., Hader, S. L., Masur, H., Young, A. T., Skillicorn, J., and Dieffenbach, C. W. (2009). Fighting HIV/AIDS in Washington, D.C. Health Aff. (Millwood) 28, 1677-1687.

Gudmundsdotter, L., Boström, A C., Burton, C., Rosignoli, G., Sandström, E., Hejdeman, B. Wahren, B., Imami, N., and Gotch, F. (2008). Long-term increase of CD4+ central memory cells in HIV-1-infected individuals by therapeutic HIV-1 rgp160 immunization. Vaccine 26, 5107-5110.

Gust, D. A., Wiegand, R. E., Kretsinger, K., Sansom, S., Kilmarx, P. H. Bartholow, B. N., and Chen, R. T. (2010). Circumcision status and HIV infection among MSM: reanalysis of a Phase III HIV vaccine clinical trial. AIDS 24, 1135-1143.

Hagger-Johnson, G., Bewick, B. M., Conner, M., O'Connor, D. B. and Shickle, D. (2011). Alcohol, conscientiousness and event-level condom use. Br. J. Health Psychol. $16,828-845$.

Hamilton, C. L., Eyzaguirre, L. M., Amarakoon, I. I., Figueroa, P., Duncan, J., Carr, J. K., and Roye, M. E. (2012). Analysis of protease and reverse transcriptase genes of HIV for antiretroviral drug resistance in Jamaican adults. AIDS Res. Hum. Retroviruses 28, 923-927.

Hanna, D. B., Selik, R. M., Tang, T., and Gange, S. J. (2011). Disparities among states in HIV-related mortality in persons with hiv infection 37 US States, 2001-2007. AIDS 6, 95-103.

Hansen, S. G., Ford, J. C., Lewis, M. S., Ventura, A. B., Hughes, C. M., Coyne-Johnson, L., Whizin, N., Oswald, K., Shoemaker, R., Swanson, T., Legasse, A. W. Chiuchiolo, M. J., Parks, C. L., Axthelm, M. K., Nelson, J. A., Jarvis, M. A., Piatak, M. Jr., Lifson, J. D., and Picker, L. J. (2011). Profound early control of highly pathogenic SIV by an effector memory T-cell vaccine. Nature 473 , 523-527.

Harris, A., Borgnia, M. J., Shi, D., Bartesaghi, A., He, H., Pejchal, R., Kang, Y. K., Depetris, R., Marozsan, A. J., Sanders, R. W., Klasse, P. J., Milne, J. L., Wilson, I. A., Olson, W. C., Moore, J. P., and Subramaniam, S. (2011). Trimeric HIV-1 glycoprotein gp140 immunogens and native HIV-1 envelope glycoproteins display the same closed and open quaternary molecular architectures. Proc. Natl. Acad. Sci. U.S.A. 108, 11440-11445.

Haynes, B. F., Fleming, J., St Clair, E. W., Katinger, H., Stiegler, G., Kuner, R., Robinson, J., Plonk, K., Staats, H. F. Ortel, T. L., Liao, H. X., and Alam, S. M. (2005). Cardiolipin polyspecific autoreactivity in two broadly neutralizing HIV-1 antibodies. Science 308, 1906-1908.

Herbst-Kralovetz, M., Mason, H. S, and Chen, Q. (2010). Norwalk virus-like particles as vaccines Expert Rev. Vaccines 9, 299-307.

Hill, A. M., Cho, M., and Mrus, J. M. (2011). The costs of full suppression of plasma HIV RNA in highly antiretroviral-experienced patients. AIDS Rev. 13, 41-48.

Hsu, J., Zinsou, C., Parkhurst, J., N'Dour, M., Foyet, L., and Mueller, D. H. (2012). Comparative costs and cost-effectiveness of behavioural interventions as part of HIV prevention strategies. Health Policy Plan. doi: 10.1093/heapol/czs021. [Epub ahead of print].

Hudgens, M. G., and Gilbert, P. B. (2009). Assessing vaccine 
effects in repeated low-dose challenge experiments. Biometrics 65, 1223-1232.

Iglesias-Ussel, M. D., and Romerio, F. (2011). HIV reservoirs: the new frontier. AIDS Rev. 13, 13-29.

Islam, F. M., Wu, J., Jansson, J., and Wilson, D. (2012a). Relative risk of cardiovascular disease among people living with HIV: a systematic review and meta-analysis. HIV Med.

Islam, F. M., Wu, J., Jansson, J., and Wilson, D. P. (2012b). Relative risk of renal disease among people living with HIV: a systematic review and meta-analysis. BMC Public Health $12,234$.

Jewkes, R. K., Dunkle, K., Nduna, M., and Shai, N. (2010). Intimate partner violence, relationship power inequity, and incidence of HIV infection in young women in South Africa: a cohort study. Lancet 376, $41-48$

Jiang, X., Burke, V., Totrov, M., Williams, C., Cardozo, T., Gorny, M. K., Zolla-Pazner, S., and Kong, X. P. (2010). Conserved structural elements in the V3 crown of HIV-1 gp120. Nat. Struct. Mol. Biol. 17, 955-961.

Jin, X., Ramanathan, M. Jr., Barsoum, S., Deschenes, G. R., Ba, L., Binley, J., Schiller, D., Bauer, D. E., Chen, D. C., Hurley, A., Gebuhrer, L., El Habib, R., Caudrelier, P., Klein, M., Zhang, L., Ho, D. D., and Markowitz, M. (2002). Safety and immunogenicity of ALVAC vCP1452 and recombinant gp160 in newly human immunodeficiency virus type 1-infected patients treated with prolonged highly active antiretroviral therapy. J. Virol. 76, 2206-2216.

Johnson, P. R., Schnepp, B. C., Zhang, J., Connell, M. J., Greene, S. M., Yuste, E., Desrosiers, R. C., and Clark, K. R. (2009). Vectormediated gene transfer engenders long-lived neutralizing activity and protection against SIV infection in monkeys. Nat. Med. 15, 901-906.

Jozkowski, K., Rosenberger, J. G., Schick, V., Herbenick, D., Novak, D. S., and Reece, M. (2010). Relations between circumcision status, sexually transmitted infection history, and HIV serostatus among a national sample of men who have sex with men in the United States. AIDS Patient Care STDS 24, 465-470.

Kalyesubula, R., and Perazella, M. A. (2011). Nephrotoxicity of HAART. AIDS Res. Treat. 2011, 562790.

Keele, B. F., Li, H., Learn, G. H., Hraber, P., Giorgi, E. E., Grayson, T., Sun, C.,
Chen, Y., Yeh, W. W., Letvin, N. L., Mascola, J. R., Nabel, G. J., Haynes, B. F., Bhattacharya, T., Perelson, A. S., Korber, B. T., Hahn, B. H., and Shaw, G. M. (2009). Low-dose rectal inoculation of rhesus macaques by SIVsmE660 or SIVmac251 recapitulates human mucosal infection by HIV-1. J. Exp. Med. 206, 1117-1134.

Keiser, O., Chi, B. H., Gsponer, T., Boulle, A., Orrell, C., Phiri, S., Maxwell, N., Maskew, M., Prozesky, H., Fox, M. P., Westfall, A., Egger, M., and IeDEA Southern Africa Collaboration. (2011). Outcomes of antiretroviral treatment in programmes with and without routine viral load monitoring in Southern Africa. AIDS 25, 1761-1769.

Kelly, J. A., Amirkhanian, Y. A., Kabakchieva, E., Vassileva, S. Vassilev, B., McAuliffe, T. L., Difranceisco, W. J., Antonova, R. Petrova, E., Khoursine, R. A., and Dimitrov, B. (2006). Prevention of HIV and sexually transmitted diseases in high risk social networks of young Roma (Gypsy) men in Bulgaria: randomised controlled trial. BMJ 333, 1098.

Kim, S. S., Peer, D., Kumar, P., Subramanya, S., Wu, H., Asthana, D., Habiro, K., Yang, Y. G., Manjunath, N., Shimaoka, M., and Shankar, P. (2010). RNAi-mediated CCR5 silencing by LFA-1-targeted nanoparticles prevents HIV infection in BLT mice. Mol. Ther. 18, 370-376.

Kindberg, E., Mickiene, A., Ax, C., Akerlind, B., Vene, S., Lindquist, L., Lundkvist, A., and Svensson, L. (2008). A deletion in the chemokine receptor 5 (CCR5) gene is associated with tickborne encephalitis. J. Infect. Dis. 197, 266-269.

Kitrinos, K. M., Amrine-Madsen, H., Irlbeck, D. M., Word, J. M., and Demarest, J. F. (2009). Virologic failure in therapy-naive subjects on aplaviroc plus lopinavir-ritonavir: detection of aplaviroc resistance requires clonal analysis of envelope. Antimicrob. Agents Chemother. 53, 1124-1131.

Koblin, B., Chesney, M., and Coates, T. (2004). Effects of a behavioural intervention to reduce acquisition of HIV infection among men who have sex with men: the EXPLORE randomised controlled study. Lancet 364, 41-50.

Kogan, S. M., Brody, G. H., Chen, Y. F., Grange, C. M., Slater, L. M., and Diclemente, R. J. (2010). Risk and protective factors for unprotected intercourse among rural African American young adults. Public Health Rep. 125, 709-717.
Koppenhaver, R. T., Sorensen, S. W. Farnham, P. G., and Sansom, S. L. (2011). The cost-effectiveness of pre-exposure prophylaxis in men who have sex with men in the United States: an epidemic model. J. Acquir. Immune. Defic. Syndr. 58 , e51-e 52.

Krakower, D., and Mayer, K. H. (2011). Promising prevention approaches: tenofovir gel and prophylactic use of antiretroviral medications. Curr HIV/AIDS Rep. 8, 241-248.

Krentz, H. B., and Gill, M. J. (2012), The direct medical costs of late presentation $(<350 / \mathrm{mm})$ of HIV infection over a 15 -year period. AIDS Res. Treat. 2012, 757135.

Kundu-Raychaudhuri, S., Sevin, A. Kilgo, P., Nokta, M., Pollard, R. B., and Merigan, T. C. (2001) Effect of therapeutic immunization with HIV type 1 recombinant glycoprotein 160 ImmunoAG vaccine in HIV-infected individuals with CD4+ T cell counts of $>$ or $=500$ and 200-400/mm3 (AIDS Clinical Trials Group Study 246/946). AIDS Res. Hum. Retroviruses 17, 1371-1378.

Kumar, R., Tuen, M., Li, H., Tse, D. B., and Hioe, C. E. (2011) Improving immunogenicity of HIV1 envelope gp120 by glycan removal and immune complex formation. Vaccine 29, 9064-9074.

Kwong, P. D., Mascola, J. R., and Nabel, G. J. (2011). Rational design of vaccines to elicit broadly neutralizing antibodies to HIV-1. Cold Spring Harb. Perspect. Med. 1, a007278.

Lafeuillade, A., and Stevenson, M (2011). The search for a cure for persistent HIV reservoirs. AIDS Rev. 13, 63-66.

Lagenaur, L. A., Sanders-Beer, B. E. Brichacek, B., Pal, R., Liu, X., Liu, Y., Yu, R., Venzon, D., Lee, P. P., and Hamer, D. H. (2011). Prevention of vaginal SHIV transmission in macaques by a live recombinan Lactobacillus. Mucosal Immunol. 4 648-657.

Lai, L., Kwa, S., Kozlowski, P. A. Montefiori, D. C., Ferrari, G. Johnson, W. E., Hirsch, V., Villinger F., Chennareddi, L., Earl, P. L., Moss, B., Amara, R. R., and Robinson, $\mathrm{H}$ L. (2011). Prevention of infection by a granulocyte-macrophage colonystimulating factor co-expressing DNA/modified vaccinia Ankara simian immunodeficiency virus vaccine. J. Infect. Dis. 204, 164-173.

Lehrman, G., Hogue, I. B., Palmer, S., Jennings, C., Spina, C. A., Wiegand, A., Landay, A. L., Coombs, R. W. Richman, D. D., Mellors, J. W. Coffin, J. M., Bosch, R. J., and Margolis, D. M. (2005). Depletion of latent HIV-1 infection in vivo: a proof-of-concept study. Lancet 366, 549-555.

Leibowitz, A. A., Parker, K. B., and Rotheram-Borus, M. J. (2011). A US policy perspective on oral preexposure prophylaxis for HIV. Am. J. Public Health 101, 982-985.

Lewis, D. J., Fraser, C. A., Mahmoud, A. N., Wiggins, R. C., Woodrow, M., Cope, A., Cai, C., Giemza, R., Jeffs, S. A., Manoussaka, M., Cole, T., Cranage, M. P., Shattock, R. J., and Lacey, C. J. (2011). Phase I randomised clinical trial of an HIV1(CN54), clade $\mathrm{C}$, trimeric envelope vaccine candidate delivered vaginally. PLoS ONE 6:e25165. doi: 10.1371/journal.pone.0025165

Li, J. Z., Brumme, Z. L., Brumme, C. J., Wang, H., Spritzler, J., Robertson, M. N., Lederman, M. M., Carrington, M., Walker, B. D., Schooley, R. T., Kuritzkes, D. R. and AIDS Clinical Trials Group A5197 Study Team. (2011). Factors associated with viral rebound in HIV-1-infected individuals enrolled in a therapeutic HIV-1 gag vaccine trial. J. Infect. Dis. 203, 976-983.

Lim, J. K., McDermott, D. H., Lisco, A., Foster, G. A., Krysztof, D., Follmann, D., Stramer, S. L., and Murphy, P. M. (2010). CCR5 deficiency is a risk factor for early clinical manifestations of West Nile virus infection but not for viral transmission. J. Infect. Dis. 201, 178-185.

Llibre, J. M., Falco, V., Tural, C. Negredo, E., Pineda, J. A., Munoz, J., Ortega, E., Videla, S., Sirera, G., Martinez, E., Miralles, C., Iribarren, J., Galindo, M. J., Domingo, P. D'Arminio-Monforte, A., Miro, J. M., and Clotet, B. (2009). The changing face of HIV/AIDS in treated patients. Curr. HIV Res. 7 , 365-377.

Long, E. F., and Owens, D. K. (2011). The cost-effectiveness of a modestly effective HIV vaccine in the United States. Vaccine 29, 6113-6124.

Lovgren Bengtsson, K., Morein, B., and Osterhaus, A. D. (2011). ISCOM technology-based Matrix M adjuvant: success in future vaccines relies on formulation. Expert Rev. Vaccines 10, 401-403.

Maggi, P., Bartolozzi, D., Bonfanti, P. Calza, L., Cherubini, C., Di Biagio, A., Marcotullio, S., Montella, F., Montinaro, V., Mussini, C., Narciso P., Rusconi, S., and Vescini, F (2012). Renal complications in HIV disease: between present and future. AIDS Rev. 14, 37-53.

Maisto, S. A., Palfai, T., Vanable, P. A., Heath, J., and Woolf-King, S. 
E. (2012). The effects of alcohol and sexual arousal on determinants of sexual risk in men who have sex with men. Arch. Sex Behav. 41, 971-986.

Manrique, M., Kozlowski, P. A., CoboMolinos, A., Wang, S. W., Wilson, R. L., Montefiori, D. C., Mansfield, K. G., Carville, A., and Aldovini, A. (2011). Long-term control of simian immunodeficiency virus mac251 viremia to undetectable levels in half of infected female rhesus macaques nasally vaccinated with simian immunodeficiency virus DNA/recombinant modified vaccinia virus Ankara. J. Immunol. 186, 3581-3593.

Margolis, D. M. (2011). Histone deacetylase inhibitors and HIV latency. Curr. Opin. HIV AIDS 6, 25-29.

Marsden, M. D., Kovochich, M., Suree, N., Shimizu, S., Mehta, R., Cortado, R., Bristol, G., An, D. S., and Zack, J. A. (2011). HIV latency in the humanized BLT mouse. J. Virol. 86, 339-347.

Mascola, J. R., Stiegler, G., Vancott, T. C., Katinger, H., Carpenter, C. B., Hanson, C. E., Beary, H., Hayes, D., Frankel, S. S., Birx, D. L., and Lewis, M. G. (2000).Protection of macaques against vaginal transmission of a pathogenic HIV-1/SIV chimeric virus by passive infusion of neutralizing antibodies. Nat. Med. 6 , 207-210.

Matalon, S., Rasmussen, T. A., and Dinarello, C. A. (2011). Histone deacetylase inhibitors for purging HIV-1 from the latent reservoir. Mol. Med. 17, 466-472.

McCarty, E. J., Quah, S., Maw, R., Dinsmore, W. W., and Emerson, C. R. (2011). Post-exposure prophylaxis following sexual exposure to HIV: a seven-year retrospective analysis in a regional centre. Int. J. STD AIDS 22, 407-408.

McCormack, S., Ramjee, G., Kamali, A., Rees, H., Crook, A. M., Gafos, M., Jentsch, U., Pool, R., Chisembele, M., Kapiga, S., Mutemwa, R., Vallely, A., Palanee, T., Sookrajh, Y., Lacey, C. J., Darbyshire, J., Grosskurth, H., Profy, A., Nunn, A., Hayes, R., and Weber, J. (2010). PRO2000 vaginal gel for prevention of HIV-1 infection (Microbicides Development Programme 301): a phase 3, randomised, double-blind, parallel-group trial. Lancet 376, 1329-1337.

Mestecky, J., Raska, M., Novak, J., Alexander, R. C., and Moldoveanu, Z. (2010). Antibody-mediated protection and the mucosal immune system of the genital tract: relevance to vaccine design. J. Reprod. Immunol. 85, 81-85.

Moir, S., and Fauci, A. S. (2009). B cells in HIV infection and disease. Nat. Rev. Immunol. 9, 235-245.

Moore, R. D. (2011). Epidemiology of HIV infection in the United States: implications for linkage to care. Clin. Infect. Dis. 52, S208-S213.

Morgan, C., Marthas, M., Miller, C., Duerr, A., Cheng-Mayer, C., Desrosiers, R., Flores, J., Haigwood, N., Hu, S. L., Johnson, R. P., Lifson, J., Montefiori, D., Moore, J., Robert-Guroff, M., Robinson, H., Self, S., and Corey, L. (2008). The use of nonhuman primate models in HIV vaccine development. PLoS Med. 5:e173. doi: 10.1371/journal.pmed.0050173

Morris, S. R., and Little, S. J. (2011). MSM: resurgent epidemics. Curr. Opin. HIV AIDS 6, 326-332.

Muster, T., Steindl, F., Purtscher, M., Trkola, A., Klima, A., Himmler, G., Rüker, F., and Katinger, H. (1993). A conserved neutralizing epitope on gp41 of human immunodeficiency virus type 1. J. Virol. 67, 6642-6647.

Myers, G. M., and Mayer, K. H. (2011). Oral preexposure anti-HIV prophylaxis for high-risk U.S. populations: current considerations in light of new findings. AIDS Patient Care STDS 25, 63-71.

Nacopoulos, A. G., Lewtas, A. J., and Ousterhout, M. M. (2010). Syringe exchange programs: impact on injection drug users and the role of the pharmacist from a U.S. perspective. J. Am. Pharm. Assoc. (2003) 50, 148-157.

Naswa, S., and Marfatia, Y. S. (2011). Pre-exposure prophylaxis of HIV. Indian J. Sex Transm. Dis. 32, 1-8.

Negri, D. R., Michelini, Z., Bona, R., Blasi, M., Filati, P., Leone, P., Rossi, A., Franco, M., and Cara, A. (2011). Integrase-defective lentiviral-vector-based vaccine: a new vector for induction of $\mathrm{T}$ cell immunity. Expert Opin. Biol. Ther. 11, 739-750.

Neuhaus, J., Jacobs, D. R., Jr., Baker, J. V., Calmy, A., Duprez, D., La Rosa, A., Kuller, L. H., Pett, S. L., Ristola, M., Ross, M. J., Shlipak, M. G., Tracy, R., and Neaton, J. D. (2011). Markers of inflammation, coagulation, and renal function are elevated in adults with HIV infection. J. Infect. Dis. 201, 1788-1795.

Nichols, W. G., Steel, H. M., Bonny, T., Adkison, K., Curtis, L., Millard, J., Kabeya, K., and Clumeck, N. (2008). Hepatotoxicity observed in clinical trials of aplaviroc (GW873140). Antimicrob. Agents Chemother. 52, 858-865.
Nishimura, Y., Igarashi, T., Haigwood, N. L., Sadjadpour, R., Donau, O. K., Buckler, C., Plishka, R. J., BucklerWhite, A., and Martin, M. A. (2003). Transfer of neutralizing IgG to macaques $6 \mathrm{~h}$ but not $24 \mathrm{~h}$ after SHIV infection confers sterilizing protection: implications for HIV1 vaccine development. Proc. Natl. Acad. Sci. U.S.A. 100, 15131-15136.

Nunn, A. S., Fonseca, E. M., Bastos, F I., Gruskin, S., and Salomon, J. A. (2007). Evolution of antiretroviral drug costs in Brazil in the context of free and universal access to AIDS treatment. PLoS Med. 4:e305. doi: 10.1371/journal.pmed.0040305

Obiako, O. R., and Muktar, H. M. (2010). Challenges of HIV treatment in resource-poor countries: a review. Niger. J. Med. 19, 361-368.

Ogert, R. A., Wojcik, L., Buontempo, C., Ba, L., Buontempo, P., Ralston, R., Strizki, J., and Howe, J. A (2008). Mapping resistance to the CCR5 co-receptor antagonist vicriviroc using heterologous chimeric HIV-1 envelope genes reveals key determinants in the C2-V5 domain of gp120. Virology $373,387-399$

O’Hagan, D. T., Rappuoli, R., De Gregorio, E., Tsai, T., and Del Giudice, G. (2011). MF59 adjuvant: the best insurance against influenza strain diversity. Expert Rev. Vaccines 10, 447-462.

Ojo, O., Verbeek, J. H., Rasanen, K., Heikkinen, J., Isotalo, L. K., Mngoma, N., and Ruotsalainen, E. (2011). Interventions to reduce risky sexual behaviour for preventing HIV infection in workers in occupational settings. Cochrane Database Syst. Rev. CD005274.

Olesen, R., Wahl, A., Denton, P. W., and Garcia, J. V. (2011). Immune reconstitution of the female reproductive tract of humanized BLT mice and their susceptibility to human immunodeficiency virus infection. J. Reprod. Immunol. 88 , 195-203.

Olive, A. J., Gondek, D. C., and Starnbach, M. N. (2011). CXCR3 and CCR 5 are both required for $\mathrm{T}$ cell-mediated protection against $\mathrm{C}$. trachomatis infection in the murine genital mucosa. Mucosal Immunol. 4, 208-216.

Owoaje, E. T., Adebiyi, A. O., and Adebayo, M. A. (2011). Sexual risk behaviours and HIV knowledge of migrant farm workers in a rural community in Nigeria. Afr. J. Med. Med. Sci. 40, 75-84.

Oyewumi, M. O., Kumar, A., and Cui, Z. (2010). Nano-microparticles as immune adjuvants: correlating particle sizes and the resultant immune responses. Expert Rev. Vaccines 9, 1095-1107.

Pace, M. J., Agosto, L., Graf, E. H., and O'Doherty, U. (2011) HIV reservoirs and latency models. Virology 411, 344-354.

Padte, N. N., Li, X., Tsuji, M., and Vasan, S. (2011). Clinical development of a novel CD1d-binding NKT cell ligand as a vaccine adjuvant. Clin. Immunol. 140, 142-151.

Palmer, S., Josefsson, L., and Coffin, J. M. (2011). HIV reservoirs and the possibility of a cure for HIV infection. J. Intern. Med. 270, 550-560.

Palucka, K., Banchereau, J., and Mellman, I. (2010). Designing vaccines based on biology of human dendritic cell subsets. Immunity 33 , 464-478.

Patel, V., Valentin, A., Kulkarni, V., Rosati, M., Bergamaschi, C., Jalah, R., Alicea, C., Minang, J. T., Trivett, M. T., Ohlen, C., Zhao, J., Robert-Guroff, M., Khan, A. S., Draghia-Akli, R., Felber, B. K., and Pavlakis, G. N. (2010). Long-lasting humoral and cellular immune responses and mucosal dissemination after intramuscular DNA immunization. Vaccine 28, 4827-4836.

Patterson, L. J., and Robert-Guroff, M. (2008). Replicating adenovirus vector prime/protein boost strategies for HIV vaccine development. Expert Opin. Biol. Ther. 8, 1347-1363.

Patterson, L. J., Kuate, S., DaltabuitTest, M., Li, Q., Xiao, P., McKinnon, K., DiPasquale, J., Cristillo, A., Venzon, D., Haase, A., and RobertGuroff, M. (2012). Replicating adenovirus-simian immunodeficiency virus (SIV) vectors efficiently prime SIV-specific systemic and mucosal immune responses by targeting myeloid dendritic cells and persisting in rectal macrophages, regardless of immunization route. Clin. Vaccine Immunol. 19 629-637.

Pejchal, R., Doores, K. J., Walker, L. M., Khayat, R., Huang, P. S., Wang, S. K., Stanfield, R. L., Julien, J. P., Ramos, A., Crispin, M., Depetris, R., Katpally, U., Marozsan, A., Cupo, A., Maloveste, S., Liu, Y., McBride, R., Ito, Y., Sanders, R. W., Ogohara, C., Paulson, J. C., Feizi, T., Scanlan, C. N., Wong, C. H., Moore, J. P., Olson, W. C., Ward, A. B. Poignard, P., Schief, W. R., Burton, D. R., and Wilson, I. A. (2011). A potent and broad neutralizing antibody recognizes and penetrates the HIV glycan shield. Science 334, 1097-1103. 
Pejchal, R., and Wilson, I. A. (2010). Structure-based vaccine design in HIV: blind men and the elephant? Curr. Pharm. Des. 16, 3744-3753.

Perrin, H., Canderan, G., Sekaly, R. P., and Trautmann, L. (2010). New approaches to design HIV-1 T-cell vaccines. Curr. Opin. HIV AIDS 5, 368-376.

Petrovsky, N., and Cooper, P. D. (2011). Carbohydrate-based immune adjuvants. Expert Rev. Vaccines 10, 523-537.

Pirrone, V., Passic, S., Wigdahl, B., and Krebs, F. C. (2012). Application and removal of polyanionic microbicide compounds enhances subsequent infection by HIV-1. Virol. J. $9,33$.

Pirrone, V., Wigdahl, B., and Krebs, F. C. (2011). The rise and fall of polyanionic inhibitors of the human immunodeficiency virus type 1 . Antiviral. Res. 90, 168-182.

Pitisuttithum, P., Gilbert, P., Gurwith, M., Heyward, W., Martin, M., Van Griensven, F., Hu, D., Tappero, J. W., and Choopanya, K. (2006). Randomized, double-blind, placebo-controlled efficacy trial of a bivalent recombinant glycoprotein $120 \mathrm{HIV}-1$ vaccine among injection drug users in Bangkok, Thailand. J. Infect. Dis. 194, 1661-1671.

Prejean, J., Song, R., Hernandez, A., Ziebell, R., Green, T., Walker, F., Lin, L. S., An, Q., Mermin, J., Lansky, A., and Hall, H. I. (2011). Estimated HIV incidence in the United States, 2006-2009. PLoS ONE 6:e17502. doi: 10.1371/journal.pone.0017502

Price, C. F., Tyssen, D., Sonza, S., Davie, A., Evans, S., Lewis, G. R., Xia, S., Spelman, T., Hodsman, P., Moench, T. R., Humberstone, A., Paull, J. R., and Tachedjian, G. (2011). SPL7013 Gel (VivaGel(R)) retains potent HIV-1 and HSV-2 inhibitory activity following vaginal administration in humans. PLoS ONE 6:e24095. doi: 10.1371/journal.pone.0024095

Pulendran, B., and Ahmed, R. (2011). Immunological mechanisms of vaccination. Nat. Immunol. 12, 509-517.

Putcharoen, O., Lee, S. H., Henrich, T. J., Hu, Z., Vanichanan, J., Coakley, E., Greaves, W., Gulick, R. M., Kuritzkes, D. R., and Tsibris, A. M. (2011). HIV-1 clinical isolates resistant to CCR5 antagonists exhibit delayed entry kinetics that correct in the presence of drug. J. Virol. 86, 1119-1128.

Ragupathi, G., Gardner, J. R., Livingston, P. O., and Gin, D. Y. (2011). Natural and synthetic saponin adjuvant QS-21 for vaccines against cancer. Expert Rev. Vaccines 10, 463-470.

Reed, S. G., Bertholet, S., Coler, R. N., and Friede, M. (2009). New horizons in adjuvants for vaccine development. Trends Immunol. 30 , 23-32.

Rehm, J., Shield, K. D., Joharchi, N., and Shuper, P. A. (2012). Alcohol consumption and the intention to engage in unprotected sex: systematic review and meta-analysis of experimental studies. Addiction 107, 51-59.

Rerks-Ngarm, S., Pitisuttithum, P., Nitayaphan, S., Kaewkungwal, J., Chiu, J., Paris, R., Premsri, N., Namwat, C., De Souza, M., Adams, E., Benenson, M., Gurunathan, S., Tartaglia, J., McNeil, J. G., Francis, D. P., Stablein, D., Birx, D. L., Chunsuttiwat, S., Khamboonruang, C., Thongcharoen, P., Robb, M. L., Michael, N. L., Kunasol, P., and Kim, J. H. (2009). Vaccination with ALVAC and AIDSVAX to prevent HIV-1 infection in Thailand. $N$. Engl. J. Med. 361, 2209-2220.

Resch, S., Korenromp, E., Stover, J., Blakley, M., Krubiner, C., Thorien, K., Hecht, R., and Atun, R. (2011). Economic returns to investment in AIDS treatment in low and middle income countries. PLoS ONE 6:e25310. doi: 10.1371/journal. pone. 0025310

Rollier, C. S., Reyes-Sandoval, A., Cottingham, M. G., Ewer, K., and Hill, A. V. (2011). Viral vectors as vaccine platforms: deployment in sight. Curr. Opin. Immunol. 23, 377-382.

Rompay, K. K. (2011). The use of nonhuman primate models of HIV infection for the evaluation of antiviral strategies. AIDS Res. Hum. Retroviruses 28, 16-35.

Rotheram-Borus, M. J., Wu, Z., Liang, L. J., Li, L., Detels, R., Guan, J., Yin, Y., and Swendeman, D. (2011). Reductions in sexually transmitted infections associated with popular opinion leaders in China in a randomised controlled trial. Sex Transm. Infect. 87, 337-343.

Routy, J., Tremblay, C., Angel, J., Trottier, B., Rouleau, D., Baril, J., Harris, M., Trottier, S., Singer, J., Chomont, N., Sekaly, R., and Boulassel, M. (2012). Valproic acid in association with highly active antiretroviral therapy for reducing systemic HIV-1 reservoirs: results from a multicentre randomized clinical study. HIV Med. 13, 291-296.

Roux, K. H., and Taylor, K. A. (2007). AIDS virus envelope spike structure. Curr. Opin. Struct. Biol. 17, 244-252.
Ryan, C. T. (2005). Trials of aplaviroc halted in treatment-naive patients. AIDS Clin. Care 17, 107-108.

Sagar, M., Wu, X., Lee, S., and Overbaugh, J. (2006). Human immunodeficiency virus type $1 \mathrm{~V} 1-\mathrm{V} 2$ envelope loop sequences expand and add glycosylation sites over the course of infection, and these modifications affect antibody neutralization sensitivity. J. Virol. 80, 9586-9598.

Santos, S. P., Amado, C. A., and Santos, M. F. (2012). Assessing the efficiency of mother-to-child HIV prevention in low- and middle-income countries using data envelopment analysis. Health Care Manag. Sci. 15, 206-222.

Sardesai, N. Y., and Weiner, D. B (2011). Electroporation delivery of DNA vaccines: prospects for success. Curr. Opin. Immunol. 23, 421-429.

Sax, P. E. (2006). Report from the 13th retrovirus conference. Vicriviroc less effective than efavirenz in treatment-naive patients. AIDS Clin. Care 18, 34-35.

Scheid, J. F., Mouquet, H., Ueberheide, B., Diskin, R., Klein, F., Oliveira, T. Y., Pietzsch, J., Fenyo, D., Abadir, A., Velinzon, K., Hurley, A., Myung, S., Boulad, F., Poignard, P., Burton, D. R., Pereyra, F., Ho, D. D., Walker B. D., Seaman, M. S., Bjorkman, P. J., Chait, B. T., and Nussenzweig, M. C. (2011). Sequence and structural convergence of broad and potent HIV antibodies that mimic CD4 binding. Science 333 1633-1637.

Schief, W. R., Ban, Y. E., and Stamatatos, L. (2009). Challenges for structure-based HIV vaccine design. Curr. Opin. HIV AIDS 4, 431-440.

Schijns, V. E., and Lavelle, E. C. (2011). Trends in vaccine adjuvants. Expert Rev. Vaccines 10, 539-550.

Schneider, K., Kerr, C. C., Hoare, A. and Wilson, D. P. (2011). Expected epidemiological impacts of introducing an HIV vaccine in thailand: a model-based analysis. Vaccine 29 , 6086-6091.

Selhorst, P., Grupping, K., Bourlet, T., Delezay, O., Arien, K. K., and Vanham, G. (2011). In vitro activity of candidate microbicides against cell-associated Hiv. Antimicrob. Agents Chemother. 56, 805-815.

Sellar, R. S., and Peggs, K. S. (2012). Therapeutic strategies for the prevention and treatment of cytomegalovirus infection. Expert Opin. Biol. Ther. doi: 10.1517/ 14712598.2012.693471. [Epub ahead of print].
Sellhorn, G., Kraft, Z., Caldwell, Z., Ellingson, K., Mineart, C., Seaman, M. S., Montefiori, D. C., Lagerquist, E., and Stamatatos, L. (2011). Engineering, expression, purification and characterization of stable clade $\mathrm{A} / \mathrm{B}$ recombinant soluble heterotrimeric gp140 proteins. J. Virol. 86, 128-142.

Shahabi, V., Maciag, P. C., Rivera, S., and Wallecha, A. (2010). Live, attenuated strains of Listeria and Salmonella as vaccine vectors in cancer treatment. Bioeng. Bugs 1, 235-243.

Shedlock, D. J., Silvestri, G., and Weiner, D. B. (2009). Monkeying around with HIV vaccines: using rhesus macaques to define 'gatekeepers' for clinical trials. Nat. Rev. Immunol. 9, 717-728.

Shimizu, S., Hong, P., Arumugam, B., Pokomo, L., Boyer, J., Koizumi, N., Kittipongdaja, P., Chen, A., Bristol, G., Galic, Z., Zack, J. A., Yang, O., Chen, I. S., Lee, B., and An, D. S. (2010). A highly efficient short hairpin RNA potently down-regulates CCR 5 expression in systemic lymphoid organs in the hu-BLT mouse model. Blood 115, 1534-1544.

Siegfried, N., Muller, M., Deeks, J. J., and Volmink, J. (2009). Male circumcision for prevention of heterosexual acquisition of HIV in men. Cochrane Database Syst. Rev. CD003362.

Siegfried, N., van der Merwe, L., Brocklehurst, P., and Sint, T. T. (2011). Antiretrovirals for reducing the risk of mother-to-child transmission of HIV infection. Cochrane Database Syst. Rev. CD003510.

Sigal, A., Kim, J. T., Balazs, A. B., Dekel, E., Mayo, A., Milo, R., and Baltimore, D. (2011). Cell-tocell spread of HIV permits ongoing replication despite antiretroviral therapy. Nature 477, 95-98.

Sigaloff, K. C., Calis, J. C., Geelen, S. P., Van Vugt, M., and De Wit, T. F. (2011). HIV-1-resistance-associated mutations after failure of firstline antiretroviral treatment among children in resource-poor regions: a systematic review. Lancet Infect. Dis. 11, 769-779.

Skoler-Karpoff, S., Ramjee, G., Ahmed, K., Altini, L., Plagianos, M. G. Friedland, B., Govender, S., De Kock, A., Cassim, N., Palanee, T., Dozier, G., Maguire, R., and Lahteenmaki, P. (2008). Efficacy of Carraguard for prevention of HIV infection in women in South Africa: a randomised, double-blind, placebo-controlled trial. Lancet 372, 1977-1987. 
Smith, D. K., Taylor, A., Kilmarx, P. H., Sullivan, P., Warner, L., Kamb, M., Bock, N., Kohmescher, B., and Mastro, T. D. (2010). Male circumcision in the United States for the prevention of HIV infection and other adverse health outcomes: report from a CDC consultation. Public Health Rep. 125, 72-82.

Smith, R. M., Carrico, A. W., Montandon, M., Kwena, Z., Bailey, R., Bukusi, E. A., and Cohen, C. R. (2011). Attitudes and beliefs about anti-retroviral therapy are associated with high risk sexual behaviors among the general population of Kisumu, Kenya. AIDS Care 23, 1668-1675.

Steward, W. T., Bharat, S., Ramakrishna, J., Heylen, E., and Ekstrand, M. L. (2012). Stigma is associated with delays in seeking care among HIV-infected people in India. J. Int. Assoc. Physicians AIDS Care (Chic.). doi: 10.1177/1545109711432315. [Epub ahead of print].

Stover, J., Korenromp, E. L., Blakley, M., Komatsu, R., Viisainen, K., Bollinger, L., and Atun, R. (2011). Long-term costs and health impact of continued global fund support for antiretroviral therapy. PLoS ONE 6:e21048. doi: 10.1371/journal.pone.0021048

Sullivan, N. L., Eickhoff, C. S., Zhang, X., Giddings, O. K., Lane, T. E., and Hoft, D. F. (2011). Importance of the CCR5-CCL5 axis for mucosal Trypanosoma cruzi protection and B cell activation. J. Immunol. 187, 1358-1368.

Swan, H., and O'Connell, D. J. (2011). The impact of intimate partner violence on women's condom negotiation efficacy. J. Interpers. Violence 27, 775-792.

Tao, W., Richards, C., and Hamer, D. (2008). Enhancement of HIV infection by cellulose sulfate. AIDS Res. Hum. Retroviruses 24, 925-929.

Tapert, S. F., Aarons, G. A., Sedlar, G. R., and Brown, S. A. (2001). Adolescent substance use and sexual risk-taking behavior. J. Adolesc. Health 28, 181-189.

Torrone, E. A., Wright, J., Leone, P. A., and Hightow-Weidman, L. B. (2010). Pregnancy and HIV infection in young women in North Carolina. Public Health Rep. 125, 96-102.

Totrov, M., Jiang, X., Kong, X. P., Cohen, S., Krachmarov, C., Salomon, A., Williams, C., Seaman, M. S., Abagyan, R., Cardozo, T., Gorny, M. K., Wang, S., Lu, S., Pinter, A., and Zolla-Pazner, S. (2010). Structure-guided design and immunological characterization of immunogens presenting the HIV-1 gp120 V3 loop on a CTB scaffold. Virology 405, 513-523.

Tovey, M. G., and Lallemand, C. (2010). Adjuvant activity of cytokines. Methods Mol. Biol. 626, 287-309.

Tritto, E., Mosca, F., and De Gregorio, E. (2009). Mechanism of action of licensed vaccine adjuvants. Vaccine 27, 3331-3334.

Trkola, A., Purtscher, M., Muster, T., Ballaun, C., Buchacher, A., Sullivan, N., Srinivasan, K., Sodroski, J., Moore, J. P., and Katinger, H. (1996). Human monoclonal antibody 2G12 defines a distinctive neutralization epitope on the gp120 glycoprotein of human immunodeficiency virus type 1. J. Virol. 70, 1100-1108.

Tsai, C. C., Follis, K. E., Grant, R., Sabo, A., Nolte, R., Bartz, C., Bischofberger, N., and Benveniste, R. (1994a). Comparison of the efficacy of AZT and PMEA treatment against acute SIVmne infection in macaques. J. Med. Primatol. 23, 175-183.

Tsai, C. C., Follis, K. E., Sabo, A., Grant, R. F., Bartz, C., Nolte, R. E., Benveniste, R. E., and Bischofberger, N. (1994b). Preexposure prophylaxis with 9-(2phosphonylmethoxyethyl)adenine against simian immunodeficiency virus infection in macaques. J. Infect. Dis. 169, 260-266.

Tudor Car, L., Van-Velthoven, M. H., Brusamento, S., Elmoniry, H., Car, J., Majeed, A., and Atun, R. (2011). Integrating prevention of mother-to-child HIV transmission (PMTCT) programmes with other health services for preventing HIV infection and improving HIV outcomes in developing countries. Cochrane Database Syst. Rev. CD008741.

Tuen, M., Visciano, M. L., Chien, P.C. Jr., Cohen, S., Chen, P. D., Robinson, J., He, Y., Pinter, A. Gorny, M. K., and Hioe, C. E. (2005). Characterization of antibodies that inhibit HIV gp120 antigen processing and presentation. Eur. J. Immunol. 35, 2541-2551.

Tyerman, Z., and Aboulafia, D. M. (2012). Review of screening guidelines for non-AIDS-defining malignancies: evolving issues in the era of highly active antiretroviral therapy. AIDS Rev. 14, 3-16.

Van Damme, L., Govinden, R., Mirembe, F. M., Guedou, F., Solomon, S., Becker, M. L., Pradeep, B. S., Krishnan, A. K., Alary, M., Pande, B., Ramjee, G., Deese, J.,
Crucitti, T., and Taylor, D. (2008). Lack of effectiveness of cellulose sulfate gel for the prevention of vaginal HIV transmission. N. Engl. J. Med. 359, 463-472.

van der Straten, A., Van Damme, L. Haberer, J. E., and Bangsberg, D. R. (2012). How well does PREP work? Unraveling the divergent results of PrEP trials for HIV prevention. AIDS 26, F13-F19.

Van Regenmortel, M. H. (2011). Limitations to the structurebased design of HIV-1 vaccine immunogens. J. Mol. Recognit. 24 741-753.

Van Regenmortel, M. H. (2012). Requirements for empirical immunogenicity trials, rather than structure-based design, for developing an effective HIV vaccine. Arch. Virol. 157, 1-20.

Vermund, S. H., Hodder, S. L., Justman, J. E., Koblin, B. A., Mastro, T. D., Mayer, K. H., Wheeler, D. P., and El-Sadr, W. M. (2010). Addressing research priorities for prevention of HIV infection in the United States. Clin. Infect. Dis. 50, S149-S155.

Vlahov, D., Robertson, A. M., and Strathdee, S. A. (2010). Prevention of HIV infection among injection drug users in resource-limited settings. Clin. Infect. Dis. 50, S114-S121.

Voelker, R. (2011). HIV/AIDS funding dropped by $10 \%$ in 2010. JAMA 306, 1642-1643.

von Wyl, V., Yerly, S., Boni, J., Shah, C., Cellerai, C., Klimkait, T., Battegay, M., Bernasconi, E., Cavassini, M. Furrer, H., Hirschel, B., Vernazza, P. L., Ledergerber, B., and Gunthard, H. F. (2011). Incidence of HIV-1 drug resistance among antiretroviral treatment-naive individuals starting modern therapy combinations. Clin. Infect. Dis. 54, 131-140.

Walensky, R. P., Paltiel, A. D., Losina, E. Morris, B. L., Scott, C. A., Rhode, E. R., Seage, G. R., and Freedberg, K. A. (2010). Test and treat DC: forecasting the impact of a comprehensive HIV strategy in Washington, D.C. Clin. Infect. Dis. 51, 392-400.

Walker, L. M., and Burton, D. R. (2010). Rational antibody-based HIV-1 vaccine design: current approaches and future directions. Curr. Opin. Immunol. 22, 358-366.

Walker, L. M., Huber, M., Doores, K. J., Falkowska, E., Pejchal, R., Julien, J. P., Wang, S. K., Ramos, A., ChanHui, P. Y., Moyle, M., Mitcham, J. L., Hammond, P. W., Olsen, O. A., Phung, P., Fling, S., Wong, C. H., Phogat, S., Wrin, T., Simek, M. D.,
Koff, W. C., Wilson, I. A., Burton, D. R., and Poignard, P. (2011). Broad neutralization coverage of HIV by multiple highly potent antibodies. Nature 477, 466-470.

Walker, L. M., Phogat, S. K., ChanHui, P. Y., Wagner, D., Phung, P., Goss, J. L., Wrin, T., Simek, M. D., Fling, S., Mitcham, J. L., Lehrman, J. K., Priddy, F. H., Olsen, O. A., Frey, S. M., Hammond, P. W., Protocol G Principal Investigators, Kaminsky, S., Zamb, T., Moyle, M., Koff, W. C., Poignard, P., and Burton, D. R. (2009). Broad and potent neutralizing antibodies from an African donor reveal a new HIV-1 vaccine target. Science 326 , 285-289.

Wamai, R. G., Morris, B. J., Bailis, S. A., Sokal, D., Klausner, J. D., Appleton, R., Sewankambo, N., Cooper, D. A., Bongaarts, J., De Bruyn, G., Wodak, A. D., and Banerjee, J. (2011). Male circumcision for HIV prevention: current evidence and implementation in sub-Saharan Africa. J. Int. AIDS Soc. 14, 49.

Wasswa, H. (2011). Ugandan AIDS care workers realign strategies as Global Fund cuts grants. BMJ 343, d8018.

Wege, A. K., Melkus, M. W., Denton, P. W., Estes, J. D., and Garcia, J. V. (2008). Functional and phenotypic characterization of the humanized BLT mouse model. Curr. Top. Microbiol. Immunol. 324, 149-165.

Wei, C., Raymond, H. F., McFarland, W., Buchbinder, S., and Fuchs, J. D. (2011). What is the potential impact of adult circumcision on the HIV epidemic among men who have sex with men in San Francisco? Sex Transm. Dis. 38, 353-355.

Weli, S. C., and Tryland, M. (2011). Avipoxviruses: infection biology and their use as vaccine vectors. Virol. J. 8, 49 .

White, T. A., Bartesaghi, A., Borgnia, M. J., De La Cruz, M. J., Nandwani, R., Hoxie, J. A., Bess, J. W., Lifson, J. D., Milne, J. L., and Subramaniam, S. (2011). Three-dimensional structures of soluble CD4-bound states of trimeric simian immunodeficiency virus envelope glycoproteins getermined by using cryoelectron tomography. J. Virol. 85, 12114-12123.

Wilkin, T. J., Su, Z., Krambrink, A., Long, J., Greaves, W., Gross, R., Hughes, M. D., Flexner, C., Skolnik, P. R., Coakley, E., Godfrey, C., Hirsch, M., Kuritzkes, D. R., and Gulick, R. M. (2010). Three-year safety and efficacy of vicriviroc, a CCR5 antagonist, in HIV-1infected treatment-experienced 
patients. J. Acquir. Immune. Defic. Syndr. 54, 470-476.

Winskell, K., Hill, E., and Obyerodhyambo, O. (2011). Comparing HIV-related symbolic stigma in six African countries: social representations in young people's narratives. Soc. Sci. Med. $73,1257-1265$.

Winstone, N., Wilson, A. J., Morrow, G., Boggiano, C., Chiuchiolo, M. J., Lopez, M., Kemelman, M., Ginsberg, A. A., Mullen, K., Coleman, J. W., Wu, C. D., Narpala, S., Ouellette, I., Dean, H. J., Lin, F., Sardesai, N. Y., Cassamasa, H., McBride, D., Felber, B. K., Pavlakis, G. N., Schultz, A., Hudgens, M. G., King, C. R., Zamb, T. J., Parks, C. L., and McDermott, A. B. (2011). Enhanced control of pathogenic Simian immunodeficiency virus SIVmac239 replication in macaques immunized with an interleukin-12 plasmid and a DNA prime-viral vector boost vaccine regimen. $J$. Virol. 85, 9578-9587.

Wirtz, V. J., Forsythe, S., Valencia-Mendoza, A., and Bautista-Arredondo, S. (2009). Factors influencing global antiretroviral procurement prices. $B M C$ Public Health 9, S6.

Wiysonge, C. S., Kongnyuy, E. J., Shey, M., Muula, A. S., Navti, O. B., Akl, E. A., and Lo, Y. R. (2011). Male circumcision for prevention of homosexual acquisition of HIV in men. Cochrane Database Syst. Rev. CD007496.

Wu, X., Yang, Z. Y., Li, Y., Hogerkorp, C. M., Schief, W. R., Seaman, M. S., Zhou, T., Schmidt, S. D., Wu, L., Xu, L., Longo, N. S., McKee,
K., O'Dell, S., Louder, M. K., Wycuff, D. L., Feng, Y., Nason, M., Doria-Rose, N., Connors, M., Kwong, P. D., Roederer, M., Wyatt, R. T., Nabel, G. J., and Mascola, J. R. (2010). Rational design of envelope identifies broadly neutralizing human monoclonal antibodies to HIV-1. Science 329, 856-861.

Wu, X., Zhou, T., Zhu, J., Zhang, B., Georgiev, I., Wang, C., Chen, X., Longo, N. S., Louder, M., McKee, K., O’Dell, S., Perfetto, S., Schmidt, S. D., Shi, W., Wu, L., Yang, Y., Yang, Z. Y., Yang, Z., Zhang, Z., Bonsignori, M., Crump, J. A., Kapiga, S. H., Sam, N. E., Haynes, B. F., Simek, M., Burton, D. R., Koff, W. C., Doria-Rose, N. A., Connors, M., NISC Comparative Sequencing Program, Mullikin, J. C., Nabel, G. J., Roederer, M., Shapiro, L., Kwong, P. D., and Mascola, J. R. (2011). Focused evolution of HIV-1 neutralizing antibodies revealed by structures and deep sequencing. Science 333, 1593-1602.

Xiao, P., Patterson, L. J., Kuate, S., Brocca-Cofano, E., Thomas, M. A., Venzon, D., Zhao, J., DiPasquale, J., Fenizia, C., Lee, E. M., Kalisz, I., Kalyanaraman, V. S., Pal, R., Montefiori, D., Keele, B. F., and Robert-Guroff, M. (2012). Replicating adenovirus-SIV recombinant priming and envelope protein boosting elicits localized, mucosal IgA immunity in rhesus macaques correlated with delayed acquisition following a repeated low dose rectal SIV $_{\text {mac251 }}$ challenge. J. Virol. 86, 4644-4657.
Xiao, X., Chen, W., Feng, Y., Zhu, Z., Prabakaran, P., Wang, Y., Zhang, M. Y., Longo, N. S., and Dimitrov, D. S. (2009). Germline-like predecessors of broadly neutralizing antibodies lack measurable binding to HIV-1 envelope glycoproteins: implications for evasion of immune responses and design of vaccine immunogens. Biochem. Biophys. Res. Commun. 390, 404-409.

Yehia, B., and Frank, I. (2011). Battling AIDS in America: an evaluation of the National HIV/AIDS Strategy. Am. J. Public Health 101, e4-e8.

Zablotska, I. B., Prestage, G., Holt, M., Poynten, M., De Wit, J., Guy, R., Mao, L., McAllister, J., and Grulich, A. E. (2011). Australian gay men who have taken nonoccupational postexposure prophylaxis for HIV are in need of effective HIV prevention methods. J. Acquir. Immune. Defic. Syndr. 58, 424-428.

Zhou, T., Georgiev, I., Wu, X., Yang, Z. Y., Dai, K., Finzi, A., Kwon, Y. D., Scheid, J. F., Shi, W., Xu, L., Yang, Y., Zhu, J., Nussenzweig, M. C., Sodroski, J., Shapiro, L., Nabel, G. J., Mascola, J. R., and Kwong, P. D. (2010). Structural basis for broad and potent neutralization of HIV1 by antibody VRC01. Science 329 , 811-817.

Zolla-Pazner, S., Cardozo, T., Decamp, A., Haynes, B., Kim, J., Kong, X., Michael, N., Rerks-Ngarm, S., and Williams, C. (2011a). "V2reactive antibodies in RV-144 vaccinees' plasma," in AIDS Vaccine 2011 Conference (Bankok, Thailand).

Zolla-Pazner, S., Kong, X. P., Jiang, X., Cardozo, T., Nadas, A., Cohen, S., Totrov, M., Seaman, M. S., Wang,
S., and Lu, S. (2011b). Cross-clade HIV-1 neutralizing antibodies induced with V3-scaffold protein immunogens following priming with gp120 DNA. J. Virol. 85, 9887-9898.

Zwick, M. B., Labrijn, A. F., Wang, M., Spenlehauer, C., Saphire, E. O., Binley, J. M., Moore, J. P., Stiegler, G., Katinger, H., Burton, D. R. and Parren, P. W. (2001). Broadly neutralizing antibodies targeted to the membrane-proximal external region of human immunodeficiency virus type 1 glycoprotein gp41. J. Virol. 75, 10892-10905.

Conflict of Interest Statement: The authors declare that the research was conducted in the absence of any commercial or financial relationships that could be construed as a potential conflict of interest.

Received: 18 May 2012; accepted: 27 July 2012; published online: 14 August 2012.

Citation: Demberg T and Robert-Guroff $M$ (2012) Controlling the HIV/AIDS epidemic: current status and global challenges. Front. Immun. 3:250. doi: 10.3389/fimmu.2012.00250

This article was submitted to Frontiers in Immunotherapies and Vaccines, a specialty of Frontiers in Immunology. Copyright (c) 2012 Demberg and Robert-Guroff. This is an open-access article distributed under the terms of the Creative Commons Attribution License, which permits use, distribution and reproduction in other forums, provided the original authors and source are credited and subject to any copyright notices concerning any third-party graphics etc. 